\title{
IMPLICACIONES REGIONALES DEL DESARROLLO ECONÓMICO DE MÉXICO
}

\author{
Elseo Mendoża BerRueto* \\ El Colegio de México
}

\section{INTRODUCCIÓN}

En este trabajo se pretende analizar la relación recíproca entre el desarrollo económico del país -considerảdo como un todo- y el desarrollo diferencial de las regiones que lo componen. Se intenta explicar, de manera general, cómo actividades que han sido fundamentales en cada etapa del desarrollo económico del país -reconocidas aquí como actividades "estratégicas"- han determinado que las regiones donde se han ubicado progresen más rápidamente que otras; a las regiones de rápido progreso se les ha denominado aquí regiones "emergentes".

Por otra parte, se puede demostrar cómo cada región emergente cuenta con uno o varios centros urbanos de crecimiento acelerado que, a manera de polos regionales de atracción, fungen como importantes centros receptores de flujos migratorios, encabezados por una fuerza de trabajo atraída principalmente por más y mejores oportunidades de trabajo, resultado del crecimiento de la economía urbana y de su proceso de diversificación. Además, en estas localidades no sólo hay concentración de actividades industriales y servicios, sino que los niveles culturales y educativos son más altos, los servicios sociales son más desarrollados y un gran sector de la población disfruta de comodidad y bienestar, de acuerdo a patrones de vida moderna.

Dentro del análisis del desarrollo económico regional se ha querido llegar hasta el intento de una explicación muy general respecto del proceso de urbanización del país, ya que es a través de la integración de importantes centros urbanos como más fácilmente se auspician los procesos de industrialización y modernización de la estructura socioeconómica, factores inseparables del proceso de desarrollo. Y esto deviene del hecho de que los centros urbanos representan mercados de oferta y demanda de factores de producción y de bienes y servicios -finales e intermedios-, cuyo tamaño permite a las grandes empresas aproximarse a su punto de operación óptima; asimismo, pueden integrar mejor sus procesos productivos horizontal o verticalmente.

- El autor agradece a Víctor L. Urquidi, a Gustavo Cabrera y a Luis Unikel sus valiosos comentarios. Este artículo es una versión modificada de un trabajo que originalmente se publicó en la revista Weltwirtschaftliches Archiv de la Universidad de Kiel, República Federal Alemana, donde apareció en el Vol. 101. Nüm. 1, septiembre de 1968. 
Por último, las áreas metropolitanas pueden ofrecer servicios diversos que representan facilidades múltiples para la función de las empresas. Todos estos factores representan diversas economías -de escala, de integración, de aglomeración y "urbanas"- que auspician un mayor y más rápido proceso de industrialización.

- No obstante lo anterior, es necesario un mínimo de cautela al tratar de asociar los procesos de industrialización y modernización con los de urbanización y desarrollo, especialmente en países en vías de desarrollo como es el caso de México. Experiencias recientes confirman que la asociación de estos procesos y su rango de causalidad no se da ni se ha dado del mismo modo ni con intensidad similar en países de diferente nivel de desarrollo relativo. Es sabido, por ejemplo, que en algunos países el proceso de urbanización ha obedecido a veces más a factores propios del subdesarrollo que a factores inherentes a una economía dinámica. Existen evidencias en el sentido de que la migración campo-ciudad - principal elemento del crecimiento urbano en los países en vías de desarrollo- suele intensificarse cuando se vuelve más precaria la situación económica del campo. De este modo, cuando las fuerzas de repulsión que operan en el medio rural (desempleo estacional o permanente, abierto o disfrazado, habitación y servicios de vivienda deficientes, educación y salud precarias, etc.) son más poderosas que las fuerzas de atracción generadas en los centros urbanos, la tasa de concentración urbana no puede identificarse de ninguna manera con la del desarrollo económico, ya que falta un elemento fundamental para impulsar los procesos de industrialización y modernización, que es la formación y acumulación de capital tanto para ampliar el aparato productivo industrial y de servicios como para ofrecer los servicios que definen a una sociedad moderna: educación, habitación, infraestructura municipal adecuada, entre otros. \&

¿En México, los centros urbanos que han crecido más rápidamente -y algunos de ellos a ritmo muy acelerado de 1940 a 1960 - corresponden a economías regionales dinámicas, identificadas claramente con las actividades estratégicas que han marcado la pauta del desarrollo nacional. Aquellos centros urbanos cuyas tasas han caído o se han convertido en localidades de rechazo se encuentran ubicados en regiones de economía decadente y poco diversificada.? Pero también es pertinente anotar que hay algunas localidades urbanás pequeñas (de 10 a 20 mil habitantes, en promedio) que a pesar de estar ubicadas en regiones de economía precaria y de no evidenciar pruebas de crecimiento económico apreciable, demográficamente han crecido con cierta rapidez (con tasas netas migratorias hasta del $4 \%$ anual) debido, con toda seguridad, más al factor "rechazo" del medio rural circundante que al factor "atracción" de la localidad urbana.

Dentro de este contexto general, se advierte que las ciudades de México son demográficamente inestables de acuerdo a su tamaño. Ciudades de 10 a 20 mil habitantes han pasado con mayor facilidad de centros de atracción a centros de rechazo o viceversa, que las ciudades de 100 mil o más habitantes, de lo cual puede inferirse que a ciudades más grandes corresponden actividades económicas más diversificadas, lo que representa mayor estabilidad demográfica, económica y social. 
En este trabajo no se intenta establecer una regionalización del país, ni siquiera por medio de agrupamientos de estados de acuerdo a condiciones socioeconómicas homogéneas. Debido a la deficiencia de las estadísticas disponibles, es difícil en México delimitar regiones económicas precisas sobre la base de criterios rigurosos. Además, aunque se pretendiera tomar a los municipios como unidades básicas para efectos de regionalización - habida cuenta de la disponibilidad de información adecuada-, inclusive los límites municipales podrian ser de poca utilidad puesto que aún dentro de tales unidades hay grandes diferencias socioeconómicas. Si aún la regionalización a nivel municipal carece de consistencia interna, la división de todo el país en regiones tomando como base los límites estatales viene a ser un instrumento de utilidad discutible.

El análisis dinámico de la economía regional sólo es posible en el plazo largo, pues sólo así pueden medirse los cambios relativos que nos interesan. Por tal motivo, aquí se intenta explicar algunas implicaciones regionales del desarrollo económico del país a partir del inicio del presente siglo. Se caracterizan tres etapas: la situación antes de la Revolución de 1910; et período de institucionalización y consolidación revolucionaria que comprende de 1921 a 1940 y la etapa de crecimiento económico sostenido que sin gran rigor puede ubicarse de 1940 a 1960. Se omite el período 1910-1921 por representar la etapa armada de la Revolución; no se continúa el análisis después de 1960 por falta de información censal y se decidió en fijar etapas coincidentes con decenios por mayor facilidad estadística.

En la última etapa y gracias a la mayor disponibilidad de estadísticas comparables, se incluye un análisis del nivel de bienestar de las entidades federativas, que se estudia como otra importante implicación regional del desarrollo económico del país. Por último, se intenta explicar el comportamiento de algunas variables demográficas a distintos niveles de bienestar de las entidades.

\section{ETAPA PRERREVOLUCIONARIA}

\section{Algunos indicadores del desarrollo}

A principios del siglo xx, México tenía 13.6 millones de habitantes, de los cuales 12 millones vivían en lugares de menos de 10 mil habitantes, siendo clasificados como población rural.*1 Se estima que en 1900 el producto nacional bruto (a precios de 1950) era casi de 8.2 miles de millones de pesos, ${ }^{2}$ resultando un producto per capita de 603 pesos anuales. Del producto total, $36 \%$ correspondió a agricultura, ganadería y silvicultura; a minería y manufactura, $24 \%$; y

* En este estudio se considera población urbana aquella que vive en localidades de 10000 o más habitantes.

1 Presidencia de la República, 50 años de Revolución Mexicana en cifras. México, 1963.

2 Todas las cifras del producto nacional incluidas en el presente trabajo corresponden a Leopoldo Solís, "La evolución económica de México a partir de la Revolución de 1910", Deviograffa y Economifa, Vol. III, Núm. 1, El Colegio de México. México, 1969. 
el restante - $40 \%$ - a transporte y otras actividades. De la población total, juzgando sólo por el nivel de ingreso, 12.4 millones correspondieron a la clase popular, 1.1 millones a la clase media y $100 \mathrm{mil}$ a la clase alta. Sólo $23 \%$ de la población mayor de 6 años sabía leer y escribir; 4.5 millones de personas estaban ocupadas en la agricultura, que absorbía el $70 \%$ del total. De acuerdo a los cálculos de Gustavo Cabrera, ${ }^{3}$ en 1901 la tasa promedio de natalidad era de cerca del 50 por millar y la tasa de mortalidad era de 32.3.

La agricultura era básicamente de tipo tradicional -tecnología poco desarrollada, baja productividad del hombre y la tierra, concentración en pocos cultivos, etc.- y se basaba en el sistema de latifundio. Se producian alrededor de 3 millones anuales de toneladas de maíz, en promedio, ${ }^{4}$ más de 2.2 millones de caña de azúcar, 300 mil de trigo, 110 mil de henequén, 50 mil de café, 34 mil de algodón y 33 mil de arroz. Había alrededor de 14 millones de cabezas de ganado mayor, un total considerable para esos tiempos, de los cuales 10.3 millones eran ganado vacuno; y cerca de 10 millones de cabezas de ganado menor.

La minería, que durante el período colonial había alcanzado gran auge, continuó siendo una actividad estratégica por excelencia. Coello Salazar afirma: "...la minería, en cambío, tendió a localizarse desde luego en las zonas Norte, Centro y Pacífico Norte. Este solo hecho contribuyó a una rápida comercialización en esas zonas, pues los minerales preciosos o industriales que producían eran vendidos en el interior o en el exterior, $y$ con el dinero adquirido de esas ventas se compraban alimentos o herramientas producidas en zonas distintas. Esto explica que durante casi toda la época porfiriana, la minería fue un estínulo constante del consumo de artículos de uso final y de uso intermedio".

De 1895 a 1910 el producto bruto minero creció a tasa media anual de $5.9 \%$; la extracción se concentraba principalmente en minerales metálicos, con oro y plata a la cabeza; era tan intensa su explotación que, por ejemplo, con respecto al oro nunca más el país ha producido los volúmenes registrados en 1910; en cuanto a la plata, sólo en 1922 volvieron a alcanzarse los niveles de 1910.

La minería era tan importante que durante la primera década del siglo representó alrededor del $60 \%$ del valor de las exportaciones, sobresaliendo el oro y la plata. México era el principal productor mundial de plata con cerca de 1800 toneladas anuales, que representaban la tercera parte de la producción mundial.

En 1892 se había establecido en Monterrey la primera fundición de plomo, y para beneficiar cobre y plomo se establecieron al año siguiente otras en Aguascalientes, en Cananea (Son.), en Concepción del Oro (Zac.) y en El Boleo (Baja California). Posteriormente, ya

3 G. Cabrera, Indicadores demograficos de México para principios de siglo, inédito, El Colegio de México.

\&egún cálculos de Moisés T. de la Peña, El pueblo y su tierra; mito y realidad de la reforma agraria en México. México, Fondo de Cultura Económica, 1964.

5 Ermilo Coello Salazar, "El comercio interior", en D. Cosío Villegas, Historia moderna de México; El Pórfiriato; Vida económica. México, Edit. Hermes, 1965. 
a principios del presente siglo, se fundaron otras plantas en Torreón, Cerralvo (S. L. P.) y Chihuahua.

La producción de petróleo en 1901 era mínima -apenas 10 mil barriles (de 159 lts.) anuales de crudo. Por otra parte, se tenían 20 mil kw de energía eléctrica instalada. Infraestructuralmente, con excepción de algunas obras de riego, sólo los ferrocarriles se desarrollaron con apreciable amplitud, pues al finalizar el siglo pasado ya se habian construido 12800 kilómetros de línea y en 1910 su red había aumentado a 19280 kilómetros.

México exportaba, aparte de minerales (oro, plata, cobre, plomo y zinc), casi exclusivamente: henequén, pieles sin curtir y caucho; 85\% de las exportaciones iban a Estados Unidos. En cambio, México importaba una serie de productos industriales de eensumo final o intermedio: aceite mineral, hulla, algodón en rama, tabaco, lana, aceite de coco, papel, hierro y acero, etc.

Las industrias se limitaban a la de textiles (en Puebla, Orizaba, Distrito Federal, Querétaro, Guadalajara), acero (Monterrey) y papel, cerillos, loza, cemento y azúcar, principalmente.

Como se puede observar por los datos anteriores, México era a principios del siglo un país prácticamente de un solo sector estratégico: minería. La agricultura le seguía en importancia con el cultivo de henequén, hule, maíz y caña de azúcar. Finalmente, la ganadería extensiva era de tercera importancia.

\section{Integración económica y social. Algunas caracteristicas regionales}

A principios del siglo el país iniciaba apenas su integración territorial; casi la mitad del área nacional estaba inhabitada y era por muchas razones inhabitable. El norte estaba aún poco integrado con el resto de la República, siendo los principales obstáculos para su colonización, entre otros, la existencia de tribus indígenas rebeldes, lo poco atractivo de sus extensas áreas desérticas $y$, en general, la escasa población del país en aquel entonces. Extensas zonas tropicales de Veracruz, Tabasco, Guerrero, Oaxaca y Michoacán eran particular: mente insalubres, predominando la malaria, la fiebre amarilla y la viruela. 'La península de Yucatán, que" había sido escenario de san-' grientas rebeliones indígenas, crecía económicamente a base del henequén y demográficamente a base de la inhumana leva de indios nativos y yaquis (estos últimos llevados de Sonora).

$=$ La parte más densamente poblada de México - como lo es en nuestros días - era la altiplanicie central, sobresaliendo el Distrito Federal; Puebla, Guanajuato, Aguascalientes, Hidalgo y Tlaxcala.

La integración económica y social del país se inicia con la migración interna, fomentada por la extensa red de comunicaciones, pero dentro de los estrechos límites determinados por la rígida estructura social del latifundismo y por los niveles de subsistencia del peonaje acasillado. La inmigración proveniente del exterior nunca fue de gran importancia a pesar de sus muchos defensores y entusiastas partidarios. En general, la mayoría de los estados de la altiplanicie central proveyeron de gente a los del Norte, especialmente a Coahuila, Chi- 
huahua y Sonora. El Distrito Federal, Veracruz, Puebla, Aguascalientes y Yucatán también recibieron un número considerable.

La intensa actividad minera, la incipiente agricultura intensiva de exportación y la extensiva de mercado interno, el importante desarrollo de algunas ramas industriales, las actividades comerciales y la ubicación del poder público estatal originaron, en general, el desarrollo más acelerado de algunas localidades urbanas del país. De este modo, a principios del siglo $\mathrm{xx}$, las principales ciudades del país eran: México, León, Puebla, Guadalajara, Monterrey, Guanajuato y San Luis Potosí; había otras de menor importancia relativa pero que crecían rápidamente: Chihuahua, Hermosillo, Aguascalientes, Colima, Cuernavaca y Mérida. En contraste, las que perdieron su antiguo ímpetu fueron: La Paz, Saltillo, Durango, Ciudad Victoria, Zacatecas, Pachuca y Guanajuato. ${ }^{6}$

En las grandes ciudades se desarrolló una importante actividad comercial regional, como efecto de la concentración demográfica urbana, la elevación de los ingresos per capita y el proceso de industrialización; a su vez, la actividad comercial auspició a cada uno de tales factores; por otra parte, en el desarrollo del comercio interno también tuvo importancia la abolición del sistema de alcabalas y la construcción de las vías férreas.

Con el estímulo de la demanda externa, algunas actividades agrícolas y ganaderas asumieron un dinamismo acelerado, incrementando su productividad como resultado de un avance en su organización y cierto progreso tecnológico. Así prosperaba en Chihuahua la ganadería; en La Laguna el algodón era el principal cultivo y la región progresaba, dando lugar a uno de los más dramáticos crecimientos urbanos. de aquel entonces, con la rápida expansión de Torreón, Gómez Palacio Y Lerdo, que acabaron por fusionäse en una sola área urbana. En Matamoros, Tamps., también se empezó a cultivar el algodón. En Chiapas, el área del Soconusco hacía aportaciones considerables de café, cacao, caña de azúcar y arroz. En Yucatán se estableció y fortaleció la economía del henequén y a base de la miseria del campesino esclavo se integró un emporio dependiente del éxito de la fibra en el mercado internacional. Campeche producía cereales y maderas. Oaxaca, a sus cultivos tradicionales agregó caña de azúcar, arroz, cacao y café. Se desarrollaron en Morelos, el norte de Guerrero y en las llanuras de Tepalcatepec, en Michoacán, las plantaciones de caña de axicar, las sementeras de maíz y trigo y abundaban los ingenios az'1careros, las fábricas de aguardiente y los molinos de trigo. En Colima se desarrollaron los cocoteros, así como árboles frutales, entre ellos limón, naranja y mango.

La región del altiplano - sección centro-occidental- era la parte más desarrollada y más densamente poblada. La agricultura floreció en el Bajío y en los valles de Sahuayo, Zamora y Jiquilpan. La industria, el comercio, las artesanías y las artes liberales progresaron en los grandes centros urbanos como Guadalajara, León, Querétaro y en menor escala Morelia y ciudades de Guanajuato. Además, esta

- Moisés González Navarro, La vida social, en D. Cosío Villegas, Historia maderna de México; El Porfiriato. Edit. Hermes, México, 1953. 
región contaba con todos los medios de comunicación entonces disponibles.?

\section{La REVOLUCIÓN INMINENTE}

De 1900 a 1910 el producto nacional bruto creció a una tasa promedio anual de $3.6 \%$ que, considerando un crecimiento demográfico de $1.09 \%$, dio un incremento promedio del producto real per capita del $2.5 \%$ anual. Destacó la minería, que creció a tasa de casi $9 \%$ anual. La agricultura había crecido al $2.8 \%$, la ganadería al $0.4 \%$ y las manufacturas al $3.1 \%$ durante el decenio. Los sectores externos -inversión y demanda extranjera- hicieron sentir su influencia en la minería y la agricultura.

Es indudable que para entonces el país atravesaba por un período de expansión económica y continuaba - aunque lento y penoso- el proceso de fusión étnica y de integración económica y social del territorio nacional. Sin embargo, el sistema político correspondía al de una dictadura que gobernaba apoyada en las clases económicamente privilegiadas y la polarización social se acentuaba por la elevada concentración del ingreso. El proletariado urbano gozaba aparentemente de mayor libertad que el proletariado rural, pero en cuanto a miseria e ignorancia es difícil precisar quiénes vivian en peores condiciones.

Este proceso de crecimiento económico, dentro de condiciones sociales crecientemente adversas, causó el nacimiento del movimiento revolucionario de 1910 que pronto se esparció a través de todos los ámbitos del país, trastornando básicamente la estructura prevaleciente.

Difícilmente puede crecer la economía de un país durante un conflicto civil generalizado. La industria sufrió estancamiento y la infraestructura detuvo su desarrollo o padeció muy serios deterioros. Muchas instituciones funcionaron deficientemente o de plano desaparecieron y no fue sino hasta después de 1921 cuando se inició la recuperación de la economía nacional, el penoso proceso de reconstrucción de lo destruido y la reorganización de la administración y hacienda públicas y de las instituciones en general.

La Revolución no se institucionalizó ni avanzó al mismo ritmo en todos los órdenes; los hombres en el poder hubieron de imaginar nuevos sistemas y organismos para reactivar el crecimiento económico del país, y una vez creados, mejorar su operación hasta que se cumplieran sus objetivos.

Desde el punto de vista del producto nacional, éste descendió en 1921 en $4 \%$ respecto a los niveles alcanzados en 1910 ; las actividades que más sufrieron retroceso fueron la ganaderia y la minería que en las estadísticas de 1921 reaparecieron con un nivel equivalente al $60 \%$ de su valor de 1910. La ganadería no tardó mucho en recuperar sus niveles anteriores a la Revolución, pero la minería prácticamente jamás logró recuperarse del todo, lo que ocasionaría con posterioridad el decaimiento económico de las regiones dedicadas principalmente

7 Para mayor información, ver: Luis González y González, "El hombre y la tierra", en D. Cosío Villegas, Historia moderna de México. La República restaurada: La vida social. México, Edit. Hermes, 1956. 
1 esta actividad. El alto nivel de la producción petrolera alcanzado $\because \because 1921$ es la única explicación de que no descendieran en mayor medida las cifras del producto bruto nacional al terminar el período armado de la Revolución.

El retroceso temporal de la agricultura y la ganadería durante la Revolución se explica precisamente porque durante el movimiento armado las diversas facciones revolucionarias absorbieron una gran cantidad de campesinos; otros, simplemente emigraron a centros ur- sanos en busca de mayor seguridad y facilidades para vivir; todo ello origínó una sería carencia de fuerza de trabajo en el campo. Por otra parte, la escasa producción agropecuaria o fue destruida deliberadamente o sirvió muthas veces para sustento de los mismos revolucionarios. Además, al derrumbar la Revolución al sistema latifundista, se provocó un descenso sustancial de las inversiones rurales y al no funcionar adecuadamente ni de manera inmediata el nuevo sistema derivado de la reforma agraria, la recuperación del sector agropecuario tenía por necesidad que ser lenta.

La producción de maíz descendió desde un promedio anual de 3.4 millones de toneladas en $1909-1913$ a 2.0 millones en el período de 1919-1923, teniéndose que importar grandes cantidades de este cereal (no fue sino hasta 1949 cuando la producción de maíz recuperó el nivel que había tenido 40 años atrás). También descendió la producción de frijol y trigo.

- En cuanto a población, la Revolución y la generalizada incidencia de la influenza española costaron al país, en conjunto, alrededor de un millón de habitantes, causando una tasa demográfica negativa (-0.51) de 1910 a 1920. En el período de 1910 a 1921, la población urbana creciơ $10 \%$ pero la rural descendió en más de un millón, esto último debido a la mortalidad antes mencionada y a la intensa migración rural-urbana. En 1910, $13.4 \%$ de la población vivía en localidades de más de 10000 habitantes y para 1921 la proporción había crecido al $16.2 \%$.

\section{La ECONOMfa dESPUÉS dE LA REVOLUCTÓN, 1921 A 1940}

Esta etapa se distingue por la reorganización del sector público de acuerdo a las funciones derivadas de los programas gubernamentales de la Revolución. Se crean en 1925 las comisiones nacionales de Irrigación y de Caminos y el Banco de México; en 1934 inicia sus operaciones la Nacional Financiera, en 1935 el Banco Nacional de Crédito Ejidal y en 1937 el Banco Nacional de Comercio Exterior. En este último año se establece la Comisión Federal de Electricidad y en 1938 se funda Petróleos Mexicanos, a raíz de la expropiación del mismo año.

\section{De 1920 a 1930}

De 1920 a 1930 la población creció al $1.6 \%$ anual, en promedio. Este reducido incremento se debió a la incidencia de la alta mortalidad que se había registrado en el decenio anterior. La población 
urbana, que en estos nueve años creció a tasa de $3.7 \%$ anual, llegó a representar la quinta parte de la población total; en cambio la rural sólo creció a poco menos del $1 \%$ anual.

A partir de 1921 y hasta 1929 -antes de la gran depresión- la economía mexicana creció a tasa anual de $4.6 \%$ en promedio, sobresaliendo la agricultura cuya tasa fue de $5.5 \%$, y la minería y las manufacturas que crecieron a tasa de $5 \%$ anual.

En mineria, los minerales industriales básicos mostraron una notable alza, especialmente el zinc, èl plomo y el cobre; la producción de plata aumentó $66 \%$, mientras que la de oro descendió $5 \%$ en el período.

\section{Cuadro 1}

México: Producción de alcunos Minerales, 1921-1929

(Toneladas).

\begin{tabular}{lcccccc}
\hline Años & Oro & Plata & Cobre & Plomo & Zinc \\
\hline 1921 & 21.4 & 2000.6 & n.d. & n.d. & n.d. \\
1922 & 23.4 & 2523.3 & 26928 & 110456 & 6142 \\
1923 & 24.3 & 2826.1 & 53372 & 155720 & 18481 \\
1924 & 24.8 & 2845.6 & 49112 & 164140 & 18936 \\
1925 & 24.5 & 2889.0 & 51336 & 171767 & 45770 \\
1926 & 23.9 & 3043.7 & 53764 & 210773 & 105474 \\
1927 & 22.4 & 3247.6 & 58672 & 243607 & 137964 \\
1928 & 21.8 & 3374.0 & 65103 & 234727 & 162023 \\
1929 & 20.4 & 3386.4 & 80560 & 247415 & 173978 \\
\hline
\end{tabular}

Fuente: Dirección General de Estadística. Anuarios.

n.d. Información no disponible.

Así como la minería se desarrollaba en función de la demanda externa, también una parte sustancial de la oferta agrícola respondía a movímientos del mercado exterior. De este modo, se desarrollaba el algodón y con él prosperaban Baja California (Norte y Sur) y Coahuila (La Laguna); con la caña de azúcar se desarrollaban Sinaloa, Veracruz, Jalisco, Tamaulipas y "Pueträ (el Estado de Morelos tardó mucho en reconstruir su industria azucarera, prácticamente hasta después de 1940). Con el tabaco prosperaban algunas regiones de Nayarit, Veracruz, Jalisco, Oaxaca y Chiapas. Otros cultivos de altos rendimientos fueron: el plátano, el cacao y el café, que se desarrollaron principalmente en las entidades de clima tropical ya mencionadas: Veracruz, Tabasco, Nayarit y Chiapas, así como en Guerrero y Oaxaca. En general, es en estos cultivos donde se inicia una explotación intensiva, desarrollada tecnológicamente, apoyada en una rápida mecanización. En cambio, los cultivos tradicionales - maiz y frijolcontinuaron cultivándose en general mediante prácticas agrícolas anticuadas. de escasos rendimientos; la situación continuó siendo más 
grave debido a la ubicación inadecuada de los cultivos desde el punto de vista ecológico, a problemas agrarios derivados de la propia reforma que en algunas áreas tuvo que atomizar la paŕcela ejidal hasta dotar al campesino de un minifundio antieconómico, la falta de inversiones y financiamientos rurales, carencia de capacidad empresarial del campesino, etc. Vastas zonas de Jalisco, Puebla, Michoacán, Estado de México y Veracruz se destinaban al maíz con rendimientos verdaderamente precarios, como los 480 kilos por hectárea en Zacatecas, 545 en el Estado de México, 625 en Michoacán, etc.; en cuanto a frijol y trigo, la situación no era mucho mejor. ${ }^{8}$

El incipiente desarrollo industrial, la minería, las actividades comerciales en expansión y en cierta medida el desarrollo agropecuario, fueron causa del desarrollo de regiones emergentes, dando lugar a un incipiente sistema de ciudades con actividades económicas bien caracterizadas; las ciudades más importantes en 1930 aparecen en el cuadro 2:

\section{Cuadro 2}

MéxtCo: Ciudades Más importantes en 1930

\begin{tabular}{lr}
\hline Ciudad & Habitantes \\
\hline México & 1029068 \\
Guadalajara & 179556 \\
Monterrey & 132577 \\
Puebla & 114793 \\
San Luis Potosi & 74003 \\
León & 69403 \\
Tampico & 68126 \\
Veracruz & 67801 \\
\hline
\end{tabular}

Fuente: V Censo General de Población.

\section{De 1930 a 1940}

En los primeros años de esta década, el país, cuya economía todania se desarrollaba "hacia afuera", continuó resintiendo profundamente los efectos de la gran depresión de la economía norteamericana, a al grado que de 1929 a 1932 el producto bruto descendió a tasa anual zromedio del $6 \%$, habiendo sido la minería la actividad que sufriera 3 mayor incidencia, pues en 3 años su producto se redujo a casi la ritad de su valor; las manufacturas descendieron $30 \%$ en el período, tos transportes $15 \%$ y el comercio $16 \%$. En 1933 se inicia la recuperación económica que luego se convierte en un proceso de desarrollo sostenido.

En la đéćađa 1930-1940 el producto bruto creció a tasa anual media 3.9, las manufacturas al $5.8 \%$, la agricultura al $2.9 \%$ y el comercio $25.1 \%$; en cambio, la minería descendió a tasa anual de $1.4 \%$.

Ya en esta década se identifican con toda claridad dos sectores

- Para mayor información, ver: V. Loredo Goytortúa, "Producción y producvidad agrícolas", en México: 50 años de Revolución, I. La economia (México, Fondo de Cultura Económica, 1967.) 
altamente dinámicos y de ubicación típicamente urbana: industrias de transformación y comercio. Al desarrollarse también la construcción y las actividades gubernamentales, se inicia un proceso de urbanización que pronto alcanzaría un ritmo elevado. Asimismo van conformándose con mayor claridad regiones económicas dinámicas en torno de cada una de las grandes concentraciones urbanas.

Las industrias que más se desarrollaron fueron: textiles, química, papel, artículos eléctricos, calzado y muebles, y otras de mayor trascendencia ulterior como hierro $\mathrm{y}^{2}$ acero, fabricacion de maquinaria diversa, armadoras de vehículos y vidrio plano.

Las localidades que más se beneficiaron con este proceso de industrialización y comercialización fueron los centros urbanos que ya habían alcanzado un tamaño considerable con anterioridad. Las principales ciudades en 1940 se incluyen en el cuadro 3.

\section{Cuadro 3}

MÉxtoo: Ciudades Más IMPORTANTES EN 1940

\begin{tabular}{llr}
\hline \multicolumn{1}{c}{ Ciudad } & Población \\
\hline México & 1448422 \\
Guadalajara & 229235 \\
Monterrey & 189092 \\
Puebla & 138491 \\
Mérida & 98852 \\
Tampico & 82475 \\
Aguascalientes & 82234 \\
San Luis Potosí & 77161 \\
Torreón & 75796 \\
Lé́n & 74155 \\
\hline
\end{tabular}

Fuente: Julio Durán Ochoa, Población. México, Fondo de Cultura Económica, 1955.

Puede apreciarse la preeminencia de la capital de la República, cuya población era casi 7 veces mayor que la ciudad de segunda importancia del país.

Desde el punto de vista agrícola, durante esta década se acentuaron las diferencias entre la agricultura de exportación y la destinada al consumo interno. La primera, de mercados más redituables y mayores beneficios, continuó su desarrollo tecnológico y de incremento de su productividad. Desde el punto de vista regional, las áreas que se desarrollaron más rápidamente fueron precisamente aquellas donde se ubicó este tipo de agricultura, principalmente en las entidades del Pacífico Norte (Sinaloa, Sonora) y Norte (Coahuila, Chihuahua, Tamaulipas). Una prueba de lo anterior son los datos respecto al nivel de mecanización de las labores agropecuarias. Según cálculos de González Santos, ${ }^{9}$ en 1930, el valor de la maquinaria empleada en la propiedad agrícola era de 10.8 millones de pesos, de los cuales $41 \%$ correspondía a los predios localizados en las zonas Pacífico Norte y Norte.

- Armando González Santos, La agricultura. México, Fondo de Cultura Económica, 1957. 
En 1940 esta proporción creció al 63\%, y en 1950 era del $67 \%$. En 5940 de 4604 tractores en Méxica el $70 \%$ se encontraban en esas áreas del norte a razón de 279 agricultores por tractor, mientras que en el resto del país la razón era de 1921.

Estas diferencias regionales en el tipo de agricultura explican variaciones no sólo en el ingreso regional, sino en otros órdenes; las nuevas zonas de agricultura comercial, produciendo principalmente para la exportación, atrajeron muchos inmigrantes, gozaron de un rápido proceso de urbanización y su infraestructura - tanto social como económica- se fortaleció a través de nuevos proyectos de regadío, introducción de energía eléctrica, nuevas y modernas carreteras, más centros de salud y enseñanza, etc. Todo esto trajo a la población regional un nivel de vida más alto que el de las zonas de agricultura tradicional, que producían principalmente bienes de subsistencia y no de comercialización.

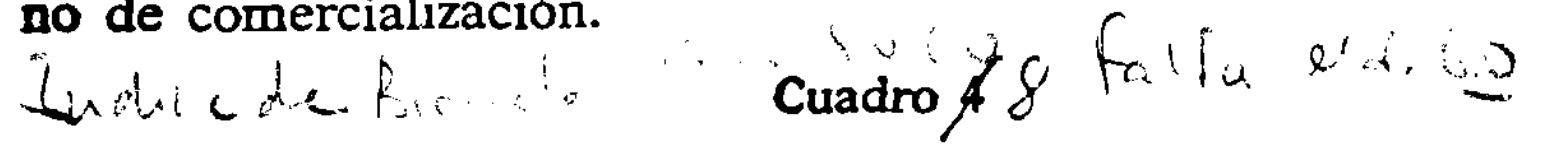

- México: Producto bruto per capita, POR ENTIDades FEderativas, 1940, 1950, 1960

(Pesos de 1960)

\begin{tabular}{|c|c|c|c|c|c|}
\hline Eat1dadea & $\begin{array}{c}\text { Poblaci i a } \\
\text { urbana }\end{array}$ & $\begin{array}{l}\text { Poblacion } \\
\text { que usa } \\
\text { calrado } \\
\text { - huarache }\end{array}$ & $\begin{array}{l}\text { Poblacion } \\
\text { que come } \\
\text { regular- } \\
\text { mente pan } \\
\text { de trigo }\end{array}$ & Alfabetismo & $\begin{array}{l}\text { Poblacion } \\
\text { ouya vi- } \\
\text { vienda } \\
\text { cuenta con } \\
\text { drenaje }\end{array}$ \\
\hline 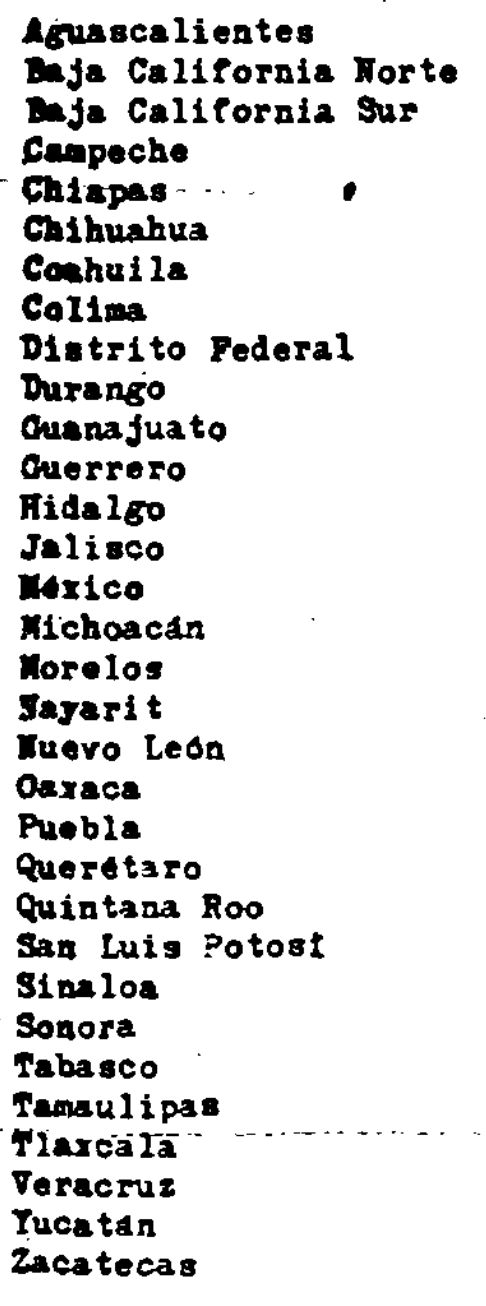 & $\begin{array}{l}59.9 \\
77.7 \\
36.3 \\
63.2 \\
24.4 \\
57.1 \\
66.7 \\
61.8 \\
95.8 \\
35.5 \\
46.4 \\
25.7 \\
22.4 \\
58.5 \\
38.6 \\
40.6 \\
53.2 \\
42.6 \\
70.4 \\
24.4 \\
39.2 \\
23.1 \\
31.4 \\
33.6 \\
38.2 \\
57.6 \\
26.6 \\
59.8 \\
43.2 \\
39.6 \\
59.8 \\
27.2\end{array}$ & $\begin{array}{l}96.1 \\
97.6 \\
95.1 \\
89.7 \\
45.5 \\
95.4 \\
96.6 \\
96.2 \\
97.1 \\
96.0 \\
95.6 \\
74.3 \\
74.2 \\
96.1 \\
80.0 \\
92.4 \\
38.9 \\
95.2 \\
96.4 \\
61.9 \\
70.0 \\
94.3 \\
95.1 \\
96.9 \\
95.9 \\
97.0 \\
48.8 \\
96.9 \\
62.1 \\
73.6 \\
95.6 \\
96.3\end{array}$ & $\begin{array}{l}56.2 \\
95.0 \\
84.4 \\
89.8 \\
64.7 \\
73.6 \\
80.3 \\
77.8 \\
94.4 \\
50.2 \\
45.9 \\
50.3 \\
51.5 \\
63.9 \\
59.9 \\
57.8 \\
87.3 \\
73.2 \\
85.6 \\
65.3 \\
53.2 \\
39.2 \\
81.2 \\
42.9 \\
75.1 \\
92.1 \\
63.7 \\
79.5 \\
40.5 \\
76.9 \\
92.1 \\
33.8\end{array}$ & $\begin{array}{l}72.9 \\
81.1 \\
79.5 \\
63.1 \\
39.3 \\
74.9 \\
80.4 \\
68.6 \\
83.4 \\
75.2 \\
51.1 \\
37.2 \\
44.0 \\
65.2 \\
57.4 \\
50.9 \\
60.9 \\
65.9 \\
80.7 \\
40.9 \\
50.2 \\
42.9 \\
64.5 \\
53.3 \\
66.0 \\
75.4 \\
61.7 \\
77.3 \\
61.5 \\
54.7 \\
65.7 \\
63.7\end{array}$ & $\begin{array}{r}42.6 \\
29.9 \\
20.1 \\
19.6 \\
13.7 \\
33.0 \\
29.7 \\
31.5 \\
69.8 \\
17.5 \\
21.8 \\
11.3 \\
14.8 \\
32.8 \\
13.5 \\
29.0 \\
28.8 \\
17.8 \\
44.3 \\
9.1 \\
19.8 \\
18.2 \\
6.7 \\
17.8 \\
18.8 \\
29.2 \\
16.7 \\
33.4 \\
12.6 \\
22.5 \\
19.5 \\
9.9\end{array}$ \\
\hline Proaedio Kacional & 52.7 & 85.7 & 68.6 & 62.2 & 28.5 \\
\hline
\end{tabular}

Fuento: Datos de E. Bennewitz y Censo General de Población. 
3. Situación económica y social de las entidades federativas en 1940

Según datos elaborados por E. Bennewitz, ${ }^{10}$ el producto bruto en 1940, medido a precios de 1960, había ascendido a 2252 pesos. Las entidades que en 1940 habían alcanzado el mayor producto per capita eran: Baja California Norte, Distrito Federal, Quintana Roo, Coahuila, Chihuahua, Sonora y Nuevo León; las de menor producto eran: Oaxaca, Guerrero, Tlaxcala, Tabasco, Chiapas y Michoacán. (Véase el cuadro 4.)

De acuerdo a cálculos preliminares sobre la estructura sectorial del producto bruto de las entidades, puede afirmarse, en general, que los más altos niveles del producto bruto per capita corresponden - a entidades cuya proporción de su producto generado en los sectores terciario y secundario es mayor que la proporción generada en los mismos sectores, a nivel nacional. Por otra parte, los menores niveles del producto bruto per capita corresponden a entidades con mayor proporción de producto generado en actividades primarias que el promedio nacional. (Véase el cuadro 5.)

\section{Cuadro 5}

México: Asignación Sectorial del producto por entidades, 1940

\begin{tabular}{lccc}
\hline \multicolumn{1}{c}{ Entidades } & $\begin{array}{c}\% P B \\
\text { Sector I }\end{array}$ & $\begin{array}{c}\% P B \\
\text { Sector II }\end{array}$ & $\begin{array}{c}\% P B \\
\text { Sector III }\end{array}$ \\
\hline Proporción nacional & 23 & 30 & 47 \\
9 Distrito Federal & 1 & 33 & 66 \\
5 Coahuila & 16 & 34 & 50 \\
19 Nuevo León & 16 & 33 & 51 \\
26 Sonora & 19 & 32 & 49 \\
12 Guerrero & 51 & 21 & 28 \\
7 Chiapas & 47 & 19 & 34 \\
20 Oaxaca & 46 & 27 & 27 \\
27 Tabasco & 39 & 19 & 42 \\
\hline
\end{tabular}

Sector. I: Actividades agropecuarias, caza y pesca.

Sector II: Actividades industriales.

Sector III: Actividades de servicios.

$$
\text { Faninite? }
$$

Con objeto de ordenar a las entidades federativas del país de acuerdo a un criterio más amplio que el económico, se elaboró un índice de bienestar con datos censales de 1940, 1950 y 1960.

Aun cuando ninguna de las variables por separado miden el nivel de bienestar, su conjunto nos conduce a resultados congruentes, lo que se comprueba por el alto grado de correlación que resülta de comparar los rangos de las entidades según el producto bruto per capita y el nivel de bienestar. Las variables del índice que se tomaron, fueron: población que usa calzado, que come usualmente pan de trigo,

10 Erik Bennewitz, Algunos aspectos de las disparidades regionales en el desarrollo económico de México, inédito, El Colegio de México, 1967. 
que sabe leer $\mathrm{y}$ escribir, que vive en localidades urbanas (aquí nos ajustames al criterio censal que denomina localidades urbanas a las de 2500 más habitantes) y cuya vivienda cuenta con servicios de agua y drenaje. Con objeto de que el índice reflejara con mayor claridad el fenómeno que se trataba de medir, fue ajustado de acuerdo al principal componente, que aquí resultó ser la población urbana. (Véanse los cuadros $6,7,8$ y 9 , y la gráfica 1.$)$ *

\section{Cuadro 6}

Méxaco: Vartables soctales usadas en el fNDice de bienestar, 1940 (Porciento de la población total en cada entidad) ${ }^{a}$

\begin{tabular}{|c|c|c|c|c|c|}
\hline Intidades & $\begin{array}{l}\text { Pobkacion } \\
\text { urbana }\end{array}$ & $\begin{array}{l}\text { Poblacion } \\
\text { que usa } \\
\text { calzado } \\
\text { - buarache }\end{array}$ & $\begin{array}{l}\text { Poblectón } \\
\text { que come } \\
\text { regular- } \\
\text { mente pan } \\
\text { de trigo }\end{array}$ & Alfabetismo & $\begin{array}{l}\text { Poblacion } \\
\text { cuja vi- } \\
\text { vienda } \\
\text { cuenta con } \\
\text { drenaje }\end{array}$ \\
\hline 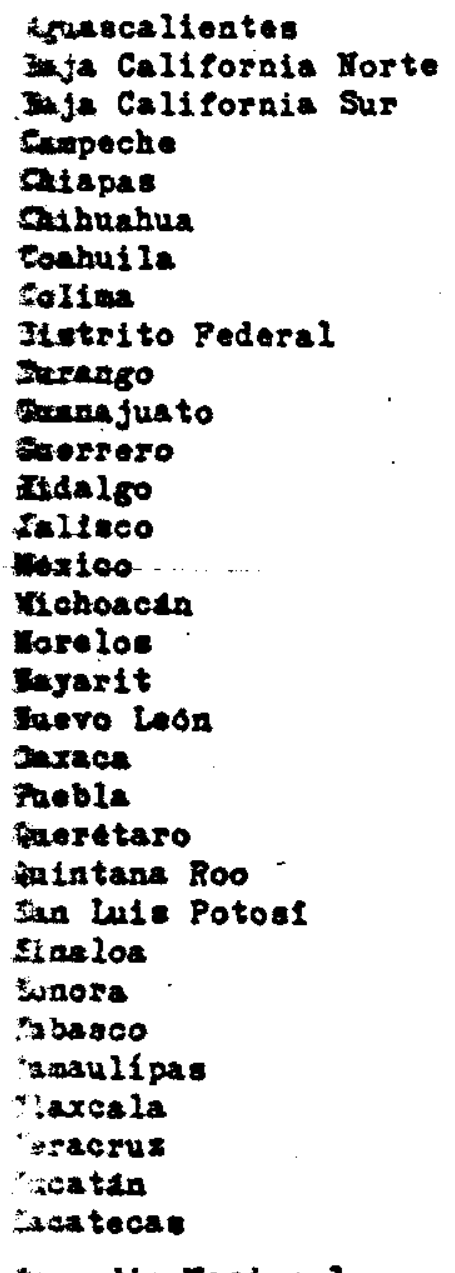 & $\begin{array}{l}57.4 \\
50.5 \\
35.8 \\
49.6 \\
16.1 \\
36.7 \\
50.6 \\
45.1 \\
93.8 \\
24.1 \\
35.1 \\
14.6 \\
18.2 \\
41.2 \\
22.7 \\
28.9 \\
27.9 \\
30.2 \\
43.9 \\
15.3 \\
27.8 \\
19.3 \\
24.9 \\
25.3 \\
21.8 \\
32.7 \\
18.0 \\
45.5 \\
29.6 \\
29.8 \\
48.7 \\
24.7\end{array}$ & $\begin{array}{l}95.7 \\
99.4 \\
89.4 \\
67.9 \\
25.4 \\
94.8 \\
97.7 \\
97.9 \\
93.6 \\
96.5 \\
89.2 \\
47.2 \\
58.0 \\
94.9 \\
52.6 \\
34.4 \\
68.7 \\
94.3 \\
96.9 \\
36.5 \\
49.6 \\
87.8 \\
70.8 \\
81.8 \\
93.4 \\
96.5 \\
24.3 \\
95.5 \\
38.3 \\
55.2 \\
35.2 \\
95.7\end{array}$ & $\begin{array}{l}47.7 \\
95.0 \\
55.8 \\
86.2 \\
37.5 \\
52.1 \\
57.5 \\
71.7 \\
87.6 \\
37.3 . \\
24.5 \\
21.1 \\
30.9 \\
40.3 \\
30.0 \\
29.5 \\
67.2 \\
62.5 \\
69.8 \\
39.8 \\
31.2 \\
22.0 \\
30.0 \\
25.2 \\
33.7 \\
73.2 \\
37.8 \\
57.2 \\
24.8 \\
55.8 \\
94.3 \\
19.7\end{array}$ & $\begin{array}{l}55.4 \\
78.3 \\
62.2 \\
50.0 \\
21.2 \\
61.1 \\
62.0 \\
58.1 \\
74.0 \\
49.9 \\
28.8 \\
19.2 \\
27.6 \\
47.5 \\
30.9 \\
29.9 \\
44.1 \\
49.0 \\
68.2 \\
20.2 \\
31.8 \\
23.1 \\
54.1 \\
33.6 \\
43.0 \\
62.0 \\
35.3 \\
64.7 \\
40.3 \\
35.9 \\
50.0 \\
41.1\end{array}$ & $\begin{array}{r}13.0 \\
19.0 \\
1.8 \\
4.5 \\
2.6 \\
10.5 \\
10.2 \\
15.5 \\
74.6 \\
7.2 \\
6.0 \\
1.4 \\
7.7 \\
9.7 \\
4.8 \\
7.0 \\
12.6 \\
6.2 \\
16.6 \\
2.8 \\
13.2 \\
8.1 \\
1.4 \\
7.5 \\
5.2 \\
7.5 \\
7.5 \\
17.3 \\
5.8 \\
10.0 \\
7.3 \\
1.9\end{array}$ \\
\hline ramodio Iacionel & 35.1 & 73.4 & 45.1 & 42.0 & 13.5 \\
\hline
\end{tabular}

Frente: Censo de población, 1940.

- Excepto en el caso del alfabetismo, donde la base está representada por población màyor de 6 años de edad.

- El autor está en deuda con Javier Bonilla y Pedro Uribe, por su valiosa Fuda en la elaboración de este índice nacional de bienestar por estados. El señor Zonilla aportó la información necesaria de la Dirección General de Estadística, donde él es Subdirector A. Pedro Uribe sugirió el esquema de ponderación estadistica usando el método de componentes principales. 


\section{Cuadro 7}

México: Vartables soctales usadas en el fNdice de-bienestar, 1950 (Porciento de la población total en cada entidad) a

\begin{tabular}{|c|c|c|c|c|c|}
\hline Intidades & $\begin{array}{c}\text { Poblacion } \\
\text { urbana }\end{array}$ & $\begin{array}{l}\text { Población } \\
\text { que usa } \\
\text { calzado } \\
\text { - buarache }\end{array}$ & $\begin{array}{l}\text { Poblacion } \\
\text { que come } \\
\text { regular- } \\
\text { mente pan } \\
\text { de trigo }\end{array}$ & Alfabetiamo & $\begin{array}{l}\text { Poblacion } \\
\text { cuya Vi- } \\
\text { rienda } \\
\text { cuenta con } \\
\text { drenaje }\end{array}$ \\
\hline $\begin{array}{l}\text { Aguascalientes } \\
\text { Baja California Norte } \\
\text { Baja California Sur } \\
\text { Campeche } \\
\text { Chiapas } \\
\text { Chibuahua } \\
\text { Coahuila } \\
\text { Colina } \\
\text { Distrito Pederal } \\
\text { Durango } \\
\text { Guanajuato } \\
\text { Guerrero } \\
\text { Hidalgo } \\
\text { Jalizco } \\
\text { Mexico } \\
\text { Michoacan } \\
\text { Horelos } \\
\text { Iayarit } \\
\text { Nuevo Ledn } \\
\text { Oaxaca } \\
\text { Puebla } \\
\text { Queretaro } \\
\text { Quintana Roo } \\
\text { San Luis Potosl } \\
\text { Sinaloa } \\
\text { Sonora } \\
\text { Tabasco } \\
\text { Tamaulipas } \\
\text { Tlaxcala } \\
\text { Veracruz } \\
\text { Tucatin } \\
\text { Zacatecas }\end{array}$ & $\begin{array}{l}54.9 \\
64.5 \\
32.9 \\
57.4 \\
23.1 \\
44.1 \\
57.4 \\
60.1 \\
94.1 \\
28.7 \\
41.6 \\
21.7 \\
21.2 \\
47.9 \\
26.4 \\
32.0 \\
43.4 \\
34.1 \\
55.9 \\
20.7 \\
33.2 \\
24.2 \\
26.9 \\
30.4 \\
27.9 \\
45.3 \\
21.9 \\
53.0 \\
39.8 \\
33.3 \\
55.2 \\
25.0\end{array}$ & $\begin{array}{l}94.0 \\
99.5 \\
89.8 \\
81.0 \\
35.3 \\
95.7 \\
97.5 \\
97.8 \\
96.9 \\
96.6 \\
93.2 \\
65.7 \\
64.2 \\
96.9 \\
64.2 \\
90.0 \\
84.3 \\
97.2 \\
95.5 \\
55.1 \\
60.5 \\
92.2 \\
85.4 \\
86.1 \\
93.6 \\
97.1 \\
39.9 \\
96.5 \\
48.3 \\
64.7 \\
95.7 \\
97.0\end{array}$ & $\begin{array}{l}42.6 \\
93.1 \\
72.2 \\
85.8 \\
41.3 \\
64.2 \\
74.5 \\
67.4 \\
93.7 \\
38.0 \\
29.4 \\
35.1 \\
37.1 \\
45.2 \\
38.8 \\
44.5 \\
78.4 \\
63.9 \\
73.4 \\
43.6 \\
40.7 \\
28.1 \\
59.6 \\
30.4 \\
53.5 \\
86.2 \\
44.1 \\
70.1 \\
30.1 \\
59.8 \\
93.0 \\
23.1\end{array}$ & $\begin{array}{l}69.2 \\
81.3 \\
77.4 \\
62.3 \\
36.1 \\
73.1 \\
74.5 \\
67.2 \\
81.8 \\
69.0 \\
45.7 \\
33.5 \\
37.1 \\
61.9 \\
49.1 \\
47.0 \\
60.0 \\
62.7 \\
78.7 \\
38.8 \\
46.0 \\
38.2 \\
63.0 \\
49.3 \\
58.5 \\
73.1 \\
58.1 \\
74.4 \\
55.9 \\
49.5 \\
64.8 \\
59.5\end{array}$ & 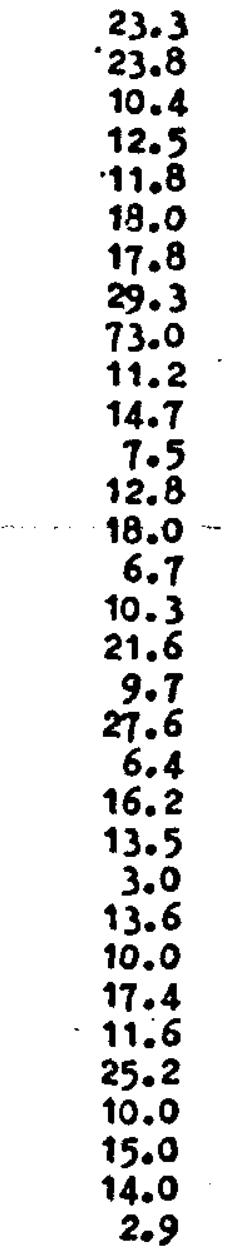 \\
\hline Promedio Macional & 42.6 & 80.9 & 54.4 & 57.5 & 20.3 \\
\hline
\end{tabular}

Fuente: Censo de Población, 1950.

- Excepto en el caso del alfabetismo, donde la base está representada por población mayor de 6 años de edad. 
Cuadro \&4

México: Vartades sociates usadas EN El fNDice de bienestar, 1960 (Porciento de la población total en cada entidad) ${ }^{2}$

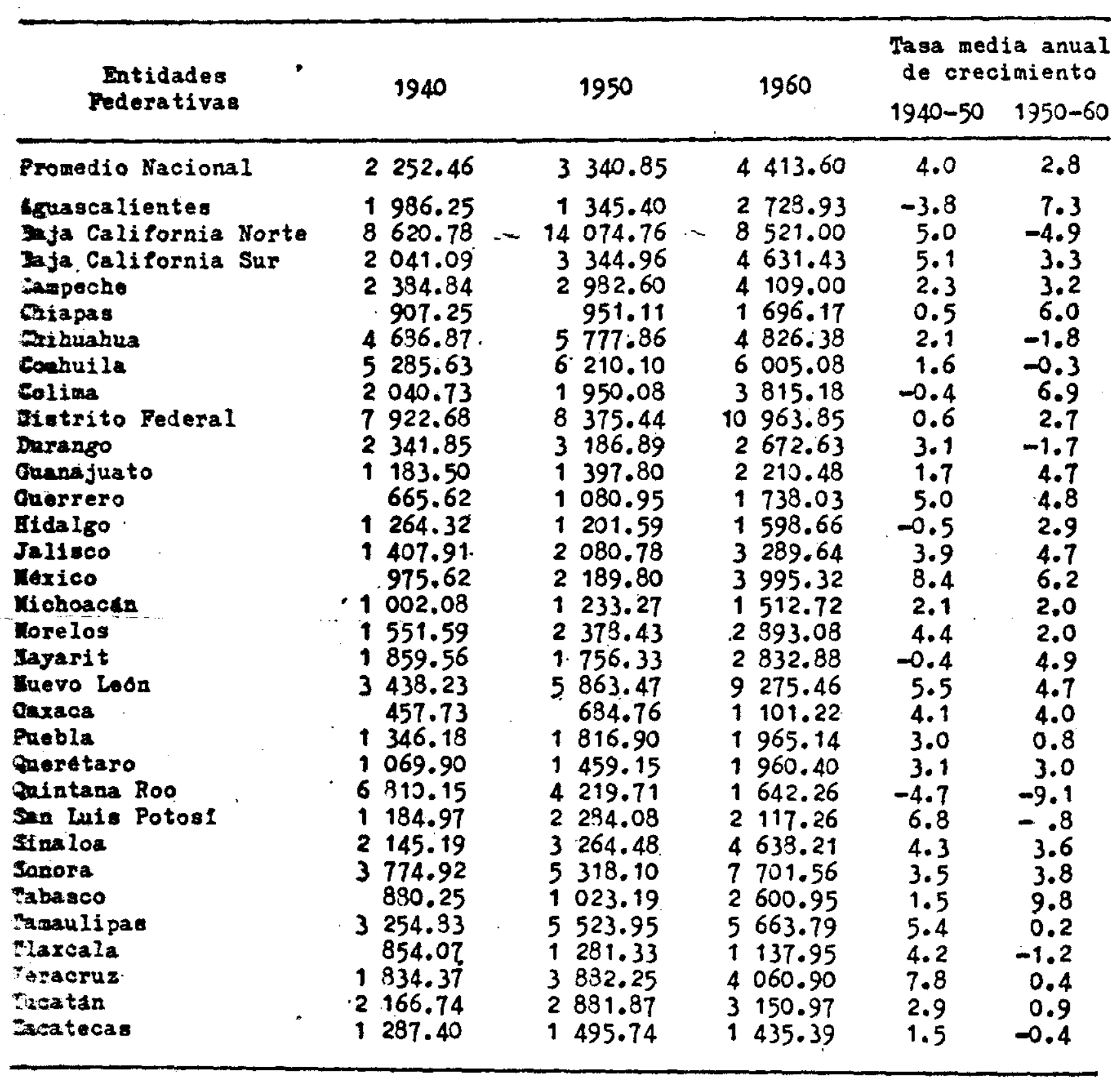

Futuente: Censo de Población, 1960.

axcepto en el caso del alfabetismo, donde la base está representada por población mayor de 6 años de edad. 
Cuadro 9

MÉxico: COMPARACTÓN DE RANGOS dE LAS ENTIDides FEDERITIVAS. Producto BRUTO PER CAPITA E fNDICE DE BIENESTAR, 1940, 1950, 1960

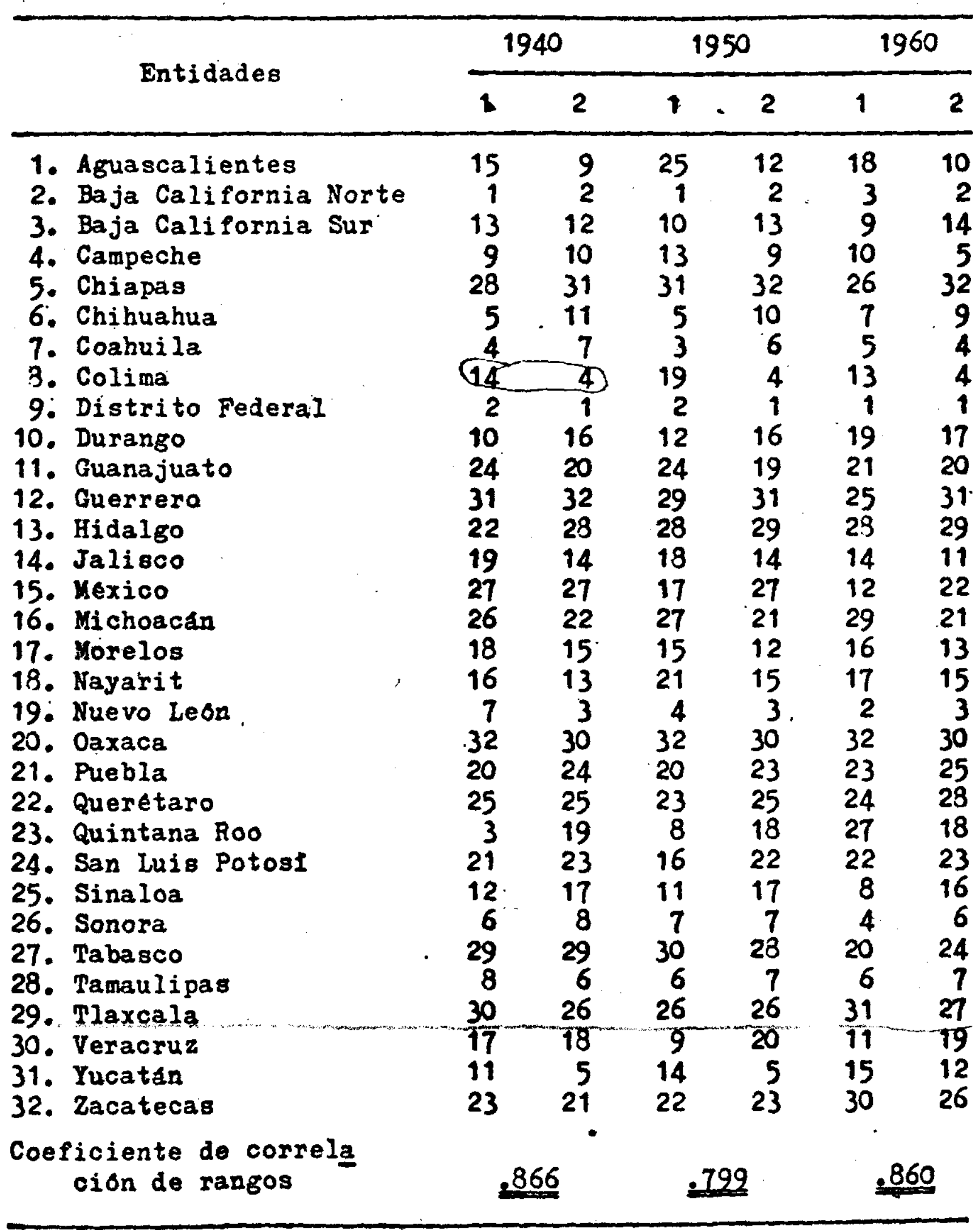

Fuente: Para el producto bruto, datos de E. Bennewitz.

1. Rango de acuerdo al producto bruto per capita.

2. Rango de acuerdo al índice de bienestar. 


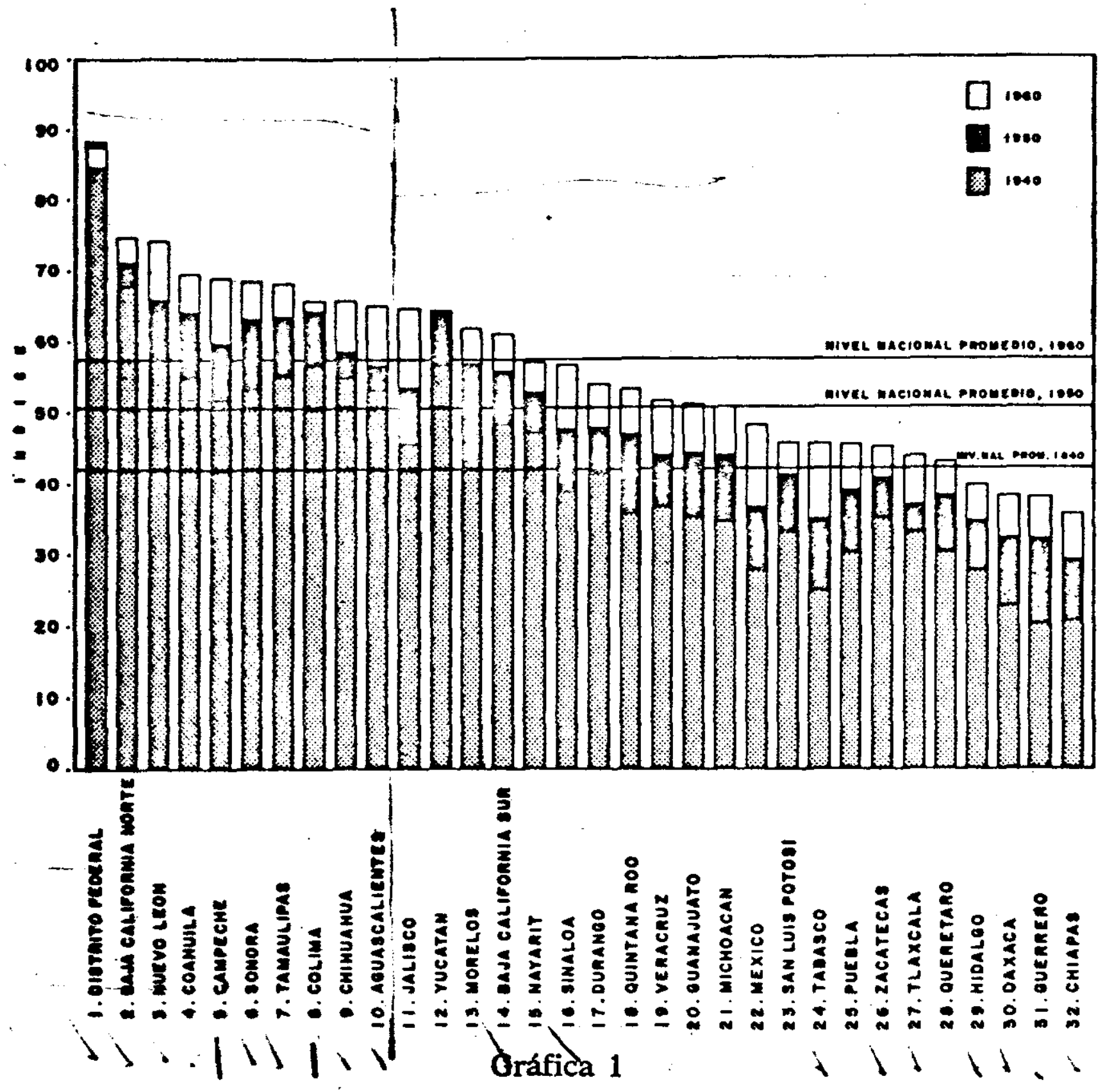

México: INDICe DE BIENESTAR POR ENTIDADES, 1940, 1950 y 1960

En cuanto a las variables demográficas, en 1940 la natalidad era de 43.5 al millar, la mortalidad general de 22.8 y la infantil de 125.7, resultando una tasa anual de crecimiento natural de $2.07 \%$. (Véase el cuadro 10.)

En general, las entidades de menor desarrollo relativo tuvieron en 1940 mayores tasas de natalidad y de mortalidad general. En cuanto a mortalidad infantil, los datos revelan niveles superiores para las entidades más desarrolladas en 1940, to que parece inadmisible a primera vista; quizá el hecho provenga de una mayor deficiencia de captación estadística precisamente en áreas más atrasadas debiło a to poco eficazmente que funcionan los registros civiles, lo incomunicado de algunas áreas, etc. (Véase el cuadro 11.) 
Cuadro 10

México: Algunas variablas demograficas a NIVEl DB BNTtDad FEDerattVa, $1940,1950 \times 1960$

(Por cada mil habitantes)

\begin{tabular}{|c|c|c|c|c|c|c|c|c|c|c|c|c|}
\hline \multirow{2}{*}{ Entidadeo Foderative } & \multicolumn{3}{|c|}{ Metal1dad } & \multicolumn{3}{|c|}{ Mortalidad. } & \multicolumn{3}{|c|}{ Mortalldad Infantil } & \multicolumn{3}{|c|}{ Creolntento antural } \\
\hline & 1940 & 1950 & 1960 & 1940 & 1950 & 1960 & 1940 & 1950 & 1960 & 1940 & 1950 & 1960 \\
\hline 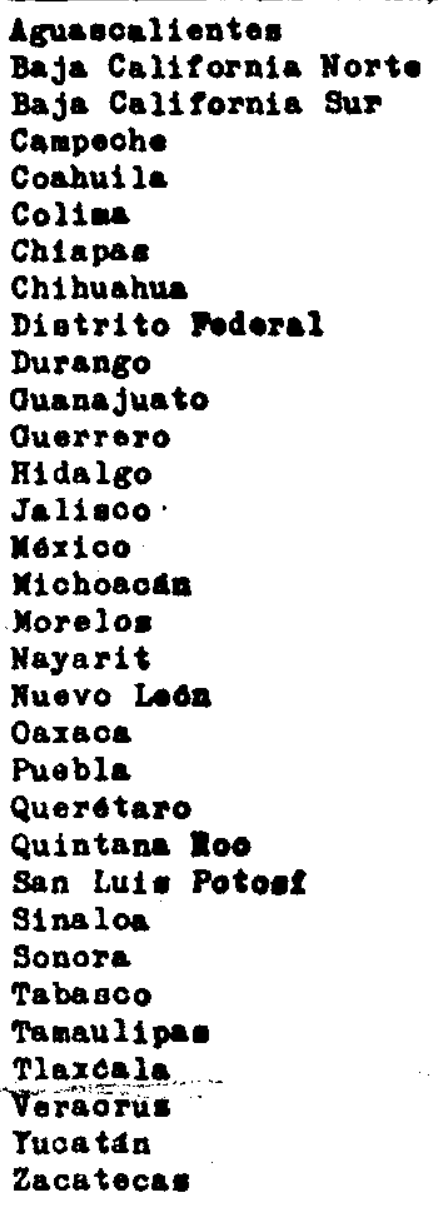 & $\begin{array}{l}48.3 \\
43.9 \\
45.4 \\
46.7 \\
61.4 \\
42.1 \\
36.7 \\
47.8 \\
33.6 \\
49.0 \\
55.5 \\
40.7 \\
39.3 \\
44.8 \\
47.0 \\
43.9 \\
46.0 \\
42.2 \\
43.7 \\
41.5 \\
44.5 \\
46.3 \\
35.7 \\
51.9 \\
36.6 \\
50.6 \\
38.4 \\
35.4 \\
53.7 \\
32.3 \\
46.0 \\
53.5\end{array}$ & $\begin{array}{l}51.0 \\
47.5 \\
39.8 \\
49.2 \\
49.2 \\
49.1 \\
43.1 \\
43.9 \\
40.5 \\
47.1 \\
49.1 \\
47.6 \\
42.0 \\
46.9 \\
47.3 \\
48.3 \\
46.7 \\
49.3 \\
43.4 \\
42.3 \\
42.8 \\
48.1 \\
41.4 \\
47.0 \\
42.0 \\
48.3 \\
46.9 \\
43.3 \\
49.1 \\
35.9 \\
43.6 \\
55.0\end{array}$ & $\begin{array}{l}53.3 \\
48.3 \\
42.4 \\
48.0 \\
49.3 \\
48.5 \\
40.2 \\
45.0 \\
43.4 \\
49.0 \\
47.4 \\
49.3 \\
46.1 \\
45.4 \\
47.9 \\
48.1 \\
49.7 \\
50.0 \\
42.2 \\
43.7 \\
46.6 \\
51.5 \\
32.5 \\
52.8 \\
49.0 \\
51.2 \\
47.0 \\
42.5 \\
51.2 \\
37.3 \\
45.9 \\
54.4\end{array}$ & $\begin{array}{l}25.2 \\
17.5 \\
12.8 \\
17.4 \\
23.5 \\
26.2 \\
18.1 \\
17.9 \\
24.2 \\
19.6 \\
23.5 \\
16.4 \\
23.0 \\
23.5 \\
26.8 \\
21.9 \\
25.5 \\
16.8 \\
17.4 \\
31.2 \\
27.8 \\
28.8 \\
10.7 \\
21.8 \\
16.4 \\
18.4 \\
14.5 \\
13.7 \\
27.4 \\
17.3 \\
24.0 \\
23.5\end{array}$ & $\begin{array}{l}17.5 \\
11.1 \\
11.5 \\
12.8 \\
13.9 \\
15.3 \\
14.2 \\
13.2 \\
15.5 \\
11.7 \\
20.5 \\
14.1 \\
20.6 \\
16.4 \\
22.6 \\
15.2 \\
15.8 \\
14.5 \\
11.6 \\
20.6 \\
20.9 \\
20.6 \\
9.5 \\
16.0 \\
11.1 \\
12.6 \\
12.6 \\
11.0 \\
22.9 \\
13.4 \\
16.6 \\
16.9\end{array}$ & $\begin{array}{r}12.0 \\
8.3 \\
7.8 \\
10.0 \\
10.1 \\
12.6 \\
12.3 \\
10.0 \\
10.2 \\
9.0 \\
13.0 \\
10.2 \\
13.6 \\
11.8 \\
14.9 \\
9.6 \\
10.0 \\
10.9 \\
8.4 \\
16.3 \\
15.9 \\
14.5 \\
5.5 \\
12.8 \\
8.6 \\
10.1 \\
9.9 \\
8.7 \\
15.9 \\
10.1 \\
12.1 \\
11.2\end{array}$ & $\begin{array}{r}156.0 \\
105.8 \\
87.1 \\
77.5 \\
114.8 \\
150.7 \\
92.7 \\
105.2 \\
196.3 \\
106.2 \\
158.6 \\
68.0 \\
120.8 \\
147.3 \\
154.8 \\
109.1 \\
104.2 \\
111.4 \\
106.2 \\
131.6 \\
142.5 \\
124.2 \\
74.4 \\
102.2 \\
104.8 \\
100.6 \\
79.6 \\
91.1 \\
145.6 \\
88.5 \\
121.3 \\
134.3\end{array}$ & $\begin{array}{r}103.3 \\
80.1 \\
81.0 \\
62.4 \\
89.6 \\
87.3 \\
75.6 \\
101.1 \\
130.2 \\
67.6 \\
119.6 \\
63.3 \\
99.4 \\
107.7 \\
144.6 \\
77.7 \\
85.1 \\
83.1 \\
80.9 \\
100.4 \\
119.9 \\
101.3 \\
70.6 \\
86.2 \\
61.3 \\
84.0 \\
70.4 \\
73.8 \\
131.0 \\
56.8 \\
84.2 \\
100.9\end{array}$ & $\begin{array}{r}74.3 \\
69.0 \\
57.7 \\
56.7 \\
71.3 \\
84.0 \\
66.0 \\
81.1 \\
85.1 \\
58.9 \\
93.7 \\
50.9 \\
69.0 \\
90.6 \\
107.9 \\
51.7 \\
48.9 \\
59.9 \\
59.8 \\
77.2 \\
91.1 \\
81.6 \\
52.0 \\
65.3 \\
46.3 \\
71.5 \\
57.9 \\
61.8 \\
110.7 \\
50.3 \\
67.6 \\
75.1\end{array}$ & $\begin{array}{l}2.3 \\
2.8 \\
2.9 \\
3.1 \\
3.8 \\
1.6 \\
1.9 \\
3.0 \\
0.9 \\
2.9 \\
2.2 \\
2.4 \\
1.6 \\
2.1 \\
2.0 \\
2.2 \\
2.0 \\
2.5 \\
2.6 \\
1.0 \\
1.7 \\
1.7 \\
2.5 \\
3.0 \\
2.2 \\
3.2 \\
2.4 \\
2.2 \\
2.6 \\
1.5 \\
2.2 \\
3.0\end{array}$ & $\begin{array}{l}29.3 \\
33.5 \\
37.1 \\
35.3 \\
35.5 \\
33.8 \\
25.2 \\
29.4 \\
22.9 \\
36.0 \\
29.2 \\
32.0 \\
24.3 \\
31.0 \\
24.8 \\
32.8 \\
28.7 \\
34.9 \\
32.1 \\
21.2 \\
22.7 \\
27.6 \\
34.4 \\
33.2 \\
37.4 \\
37.7 \\
31.2 \\
31.8 \\
28.6 \\
33.4 \\
28.5 \\
39.8\end{array}$ & $\begin{array}{l}41.3 \\
40.0 \\
34.6 \\
38.0 \\
38.6 \\
36.0 \\
27.9 \\
35.0 \\
33.3 \\
40.0 \\
34.4 \\
39.1 \\
32.6 \\
33.6 \\
33.0 \\
38.5 \\
39.7 \\
39.1 \\
38.8 \\
27.4 \\
30.7 \\
37.0 \\
26.9 \\
40.0 \\
40.4 \\
41.1 \\
37.1 \\
33.9 \\
35.4 \\
27.2 \\
33.8 \\
43.3\end{array}$ \\
\hline Total Naciomel & 43.5 & 45.5 & 46.0 & 22.8 & 16.2 & 11.5 & 125.7 & 96.2 & 74.2 & 2.1 & 29.3 & 34.5 \\
\hline
\end{tabular}

Fuente: Dirección General de Estadistica. 


\section{Cuadro 11}

MÉxico: INDICES PONDERIDOS DE NATALIDAD, MORTALIDAD Y MORTALIDAD INFANTIL POR ENTIDADES DE DISTINTO NIVEL DE BIENESTAR, 1940, 1950, 1960

\begin{tabular}{|c|c|c|c|c|c|c|}
\hline Grupos de entidades & 1940 & 1950 & 2960 & $\begin{array}{l}\text { Cambio de } \\
1940-1950 \\
\end{array}$ & $\begin{array}{l}\text { Cambio de } \\
1950-1960 \\
\end{array}$ & $\begin{array}{l}\text { Cambio de } \\
1940-1960 \\
\end{array}$ \\
\hline & \multicolumn{6}{|c|}{ Indice de natalidad (a) } \\
\hline $\begin{array}{l}30 \text { Estados de mas al to } \\
\text { nivel.de bienestar }\end{array}$ & 43.0 & 43.5 & 44.9 & +1.16 & +3.22 & +4.42 \\
\hline $\begin{array}{l}10 \text { Estados de mas bajo } \\
\text { nivel de bienestar }\end{array}$ & 43.5 & 46.7 & 47.2 & +7.35 & +1.07 & +8.51 \\
\hline \multirow{2}{*}{ Macional } & 43.5 & 45.5 & 46.0 & 4.60 & +1.09 & +5.75 \\
\hline & \multicolumn{6}{|c|}{ Indice de mortalidad (a) } \\
\hline $\begin{array}{l}20 \text { Estados de mise al to } \\
\text { nivel de bicnestar }\end{array}$ & 21.3 & 13.9 & 20.0 & -34.74 & -28.06 & -53.05 \\
\hline $\begin{array}{l}10 \text { Estados de nas bajo } \\
\text { nivel de bienestar }\end{array}$ & 24.5 & 19.5 & 13.6 & -20.41 & -30.26 & -44.49 \\
\hline \multirow[t]{2}{*}{ Macional } & 22.8 & 16.2 & 11.5 & -28.95 & -29.01 & -49.56 \\
\hline & & \multicolumn{5}{|c|}{ Indice de mortalidad infantil (b) } \\
\hline $\begin{array}{l}20 \text { Estados de mas alto } \\
\text { nivel de biencstar }\end{array}$ & 140.6 & 102.5 & 77.5 & -27.10 & -24.39 & -44.89 \\
\hline $\begin{array}{l}10 \text { Estados de mis bajo } \\
\text { nivel de bienestar }\end{array}$ & 122.9 & 205.6 & 74.1 & -12.08 & -29.83 & -39.71 \\
\hline Macional & 125.7 & 96.2 & 74.2 & -23.47 & -22.87 & -40.97 \\
\hline
\end{tabular}

Fuente: Dirección General de Estadística.

(a) Tasa por cada mil habitantes.

(b) Tasa por cada mil nacidos vivos.

V. El CRECIMIENTO ECONÓMICO ACELERADO, 1940-1960

1. De 1940 a 1950

Durante esta decenio alcanzó su máximo nivel la dependencia externa de la economía mexicana, debido al aumento sustanctal de sus exportaciones con motivo de la segunda guerra mundial, pero es tambien en este período cuando se inicia el proceso de desarrollo "hacia adentro", precisamente a raíz de los cambios en el comercio exterior đerivados de la terminación del conflicto mundial.

La guerra estimuló el desarrollo industrial tanto por la necesidad de satisfacer la demanda de algunos productos, insatisfecha por la oferta exterior, como por la mayor exportación de algunos productos industriales - textiles - o materias primas - minerales-. Esto último originó un proceso de reactivación económica de algunas regiones mineras, que habian decaído con anterioridad. 
Al término de la guerra, la economía mexicana empezó a experimentar muy serios problemas. Las exportaciones descendieron bruscamente - minerales y textiles, principalmente- y la demanda de importaciones se expandió cuando los oferentes extranjeros estuvieron otra vez en capacidad de satisfacer estas demandas, por reconversión a estructuras productivas de tiempo de paz. Este profundo desequilibrio con el exterior trajo por consecuencia una devaluación del orden del $32 \%$ en 1948, que además era inevitable, pues en tal año hubo todo un movimiento de ajuste mundial de paridades.

De 1940 a 1950 el producto nacional creció a tasa media anual de $6 \%$, la agricultura al $7.9 \%$, las manufacturas al $7.1 \%$ y el comercio al $6.1 \%$. Las actividades primarias participaron con el $22.5 \%$ del producto bruto, los industriales con el $30.4 \%$ y con el $47.1 \%$ los servicios.

Desde el punto de vista demográfico, el país experimentó un notable ascenso en su tasa de crecimiento debido al efecto combinado de una elevación de la natalidad - de 43.5 a 45.5 al millar- y un descenso de la tasa de mortalidad que de 22.8 bajó a 16.2; por su parte, la mortalidad infantil descendió de 125.7 a 96.2. Así, el crecimiento natural ascendió a $2.93 \%$ en 1950.

Es decir, que a nivel nacional la natalidad se elevó en $4.6 \%$ en el decenio, la mortalidad descendió en $29 \%$ y la mortalidad infantil en $23.5 \%$.

En cuanto al comportamiento de las variables demográficas al nivel de las entidades federativas y según las hemos dividido en dos grupos - las desarrolladas y las menos desarrolladas-, encontramos que el índice de natalidad creció en $1.2 \%$ en el decenio en los diez estados de más alto nivel de bienestar $\overline{\mathrm{y}} \mathbf{7 . 4} \%$ en los de más bajo nivel. Esto podría inducir a afirmar que a medida que se mejoran los niveles de bienestar (incluyendo la educación y el proceso de urbanización) la fecundidad tiende a disminuir -0 a que sus incrementos sean menores-; sin embargo, la tendencia es tan errática en estas entidades que nada se puede asegurar al respecto. En donde es más clara ta influencia de los.más altos niveles de bienestar es tanto en las tasas de mortalidad general como infantil, puesto que ambas descienden más rápidamente en las entidades de mayor nivel de bienestar que en las más atrasadas. (Véase el cuadro 11.)

En los sectores económicos, el agropecuario creció notablemente en este decenio. Sobre un índice con base en 1900, el volumen de la producción agrícola ascendió de 145.0 en 1940 a 238.7 en 1950; el algodón aumentó 4 veces el volumen de su producción, el maíz 3 veces y más que duplicaron su producción la caña de azúcar y el ajonjolí. ${ }^{11}$

Entre las causas del incremento agrícola durante este decenio pueden citarse: la política agraria en apoyo de la pequeña propiedad, las fuertes inversiones en obras de riego, la ampliación del crédito agrícola y en general la expansión de la infraestructura económica - electrificación y caminos, principalmente.

Las regiones más beneficiadas con importantes obras de riegó fueron el Norte y el Pacífico Norte. Las obras más relevantes terminadas en esta década aparecen en el cuadro 12.

11 Presidencia de la República, op. cit. 
Cuadro 12

México: Algunas obras de riego de las regiones Norte y Pacífico Norte, TERILLNADAS EN LA DÉCADA 1940-1950

\begin{tabular}{llr}
\hline \multicolumn{1}{c}{ Entidad } & \multicolumn{1}{c}{ Nombre de la presa } & $\begin{array}{c}\text { Hectáreas } \\
\text { beneficiadas }\end{array}$ \\
\hline $\begin{array}{llr}\text { Durango-Coahuila (La Laguna) } \\
\text { Sonora }\end{array}$ & Lázaro Cárdenas & 113000 \\
$\begin{array}{l}\text { Valle del Yaqui } \\
\text { Hermosillo }\end{array}$ & Angostura & 200000 \\
Tamaulipas & Abelardo L. Rodríguez & 10000 \\
Chihuahua \\
$\begin{array}{l}\text { Valle Delicias } \\
\text { Sinaloa } \\
\text { Culiacán }\end{array}$ & Marte R. Gómez & 66145 \\
\hline
\end{tabular}

Fuente: Adolfo Orive Alba, "Las obras de irrigación", en México: 50 años de Revolución, I. La economía. México, Fondo de Cultura Económica, 1960.

Desde luego que hubo otras obras de importancia como la Presa Solís en el Río Lerma ( 102000 hectáreas beneficiadas) y la Presa Cuarenta, en Jalisco, pero desde el punto de vista regional, el Pacífico Norte y el Norte fueron zonas altamente privilegiadas en materia de gran irrigacióp. En general, de 1939 a 1946, la gran irrigación ábsorbió cerca dol $90 \%$ de la inversión pública en agricultura. Aunque el grueso de las inversiones se hizo durante el decenio 1940-1950, gran parte de su impacto en las economías regionales fue de efecto diferido ya que sus sistemas de riego no fueron completados sino hasta después.

Las nuevas tierras se destinaron a cultivos alta costa y-rendimiento, principalmente para exportaciones. Para estos cultivos se contó con creciente financiamiento privado y oficial, lo que auspició el equipamiento y desarrollo tecnológico de las labores agropecuarias. Las regiones donde se ubicaron estas obras y actividades progresaron rápidamente y siempre hubo una localidad de concentración demográfica y de actividades comerciales y de servicios que sirviera de polo regional de crecimiento. El rápido desenvolvimiento de ciudades como Torreón, Hermosillo, Matamoros, Culiacán y Delicias comprueba tal aserto.

Por lo que toca a la industria, ésta se desarrolló én general dé acuerdo a las condiciones impuestas por. la II Guerra Mundial, tanto en lo concerniente a mercados internos como externos, incrementándose más rápidamente las de cemento, hierro y acero, textiles y azúcar, celulosa y papel, productos químicos y fertilizantes, así como empaque de carnes. Por otra parte, se integró la industria siderúrgica nacional.

En petróleo las inversiones fueron escasas de 1938 a 1944, pero luego empezaron a ascender rápidamente, hasta llegar a 398 millones en 1950 para perforación, refinerías y construcción de oleoductos, transporte de equipo y almacenamiento, etc. El ritmo creciente de la economía se traducía en un incremento sostenido de la demanda de 
energéticos que había que satisfacer tanto a corto como a largo plazo; de ahí el aumento tan considerable de las inversiones.

A fines de la década fueron disminuyendo las inversiones en la minería debido al agotamiento de los mejores yacimientos, a la caída de los precios internacionales y a la inseguridad de los mercados, lo que originó una grave obsolecencia del equipo. El cobre continuó decayendo pero el plomo y el zinc alcanzaron sus máximos niveles en esta década.

En cuanto a sus implicaciones regionales, el proceso de industrialización fortaleció centros urbanos que para entonces eran ya de importancia -México, Monterrey, Guadalajara- y que tenían un bien desarrollado sistema de comunicaciones; con esto se incrementó la concentración industrial. Muchas industrias, en lugar de establęcerse cerca de los abastecimientos de materias primas, prefirieron radicar junto a los grandes mercados - centros urbanos- debido a economías externas, pero también por las deficiencias del servicio ferrocarrilero; por otra parte, las tarifas ferroviarias en vigor fueron disenadas para subsidiar el transporte de materias primas y no el de los productos ya elaborados. También, la todavía inadecuada distribución de combustibles y la carencia de energía eléctrica fueron factores que impidieron una distribución geográfica más equilibrada de las actividades industriales.

- La longitud de las carreteras se duplicó de 1939 a 1944 y al finalizar la II Guerra Mundial se intensificó el tráfico carretero, ya que el país pudo abastecerse de unidades de transporte, una vez que las fábricas norteamericanas volvieron a su producción de tiempos de paz. El desarrollo de este tráfico fue más rápido en las regiones del Norte, Occidentat y Naroccidental del país, debido a su considerable crecimiento agrícola, industrial y demográfico. El tonelaje movilizado aumentó entre 1941 y 1950 en todos los tipos de transporte. En la región del Golfo, Sur y Sureste hubo una sustitución del barco y el ferrocarril, por el camión, el avión, el oleoducto y el gasoducto.12

En la década 1940-1950, las regiones "emergentes", las que más rápidamente respondieron al crecimiento económico sostenido en que se había iniciado el país, y en cuyo proceso participaron de manera relevante, fueron:

1) Las que surgieron y evolucionaron al recibir nuevas industrias estratégicas para el desarrollo nacional: la de hierro y acero en Coahuila y Nuevo León; la de cemento en el Distrito Federal, Jalisco, Nuevo León y Chihuahua; la de petróleo en Veracruz y Tamaulipas y sus procesos de refinación en el Distrito Federal y Guanajuato.

2) Las favorecidas con las grandes obras de riego, cuya superficie beneficiada se destinó a cultivos de alto valor, generalmente de exportación, apoyados por amplio financiamiento $\mathrm{y}$ aplicando tecnología y equipo moderno: Sinaloa, Coahuila y Durango (La Laguna), Tamaulipas y Chihuahua. Tan solo estas áreas contaban con el $85 \%$ del total de superficie de riego del país en 1950.

3) Las entidades beneficiadas con la ampliación del sistema de ca-

12 Comisión Mixta, El desarrollo económico de México y su capacidad para absorber capital del exterior. México, Fondo de Cultura Económica, 1962. 
rreteras y en especial, aquellas en donde se desarrolló rápidamente el servicio de auto-transporte, que fueron principalmente las del Norte, Occidente y Noroccidente del país.

4) Las que ya tenían una ciudad importante, estímulo de atracción para los nuevos o ampliados establecimientos industriales, las actividades comerciales y de servicios en general. Aquí pueden anotarse el Distrito Federal, Nuevo León, Jalisco y Puebla, entre otras.

\section{El proceso de urbanización de 1940 a 1950}

El cuadro 13 muestra las ciudades de más rápido incremento de 1940 a $1950 . .^{13}$ De éstas 19 ciudades, centros de economías regionales,

Cuadro 13

México: Ciudades de más alto CRecimiento, 1940.1950

\begin{tabular}{|c|c|c|c|c|}
\hline \multirow{2}{*}{ Giudad } & \multirow{2}{*}{$\begin{array}{l}\text { Roblaoion } \\
\text { on } 1940\end{array}$} & \multirow{2}{*}{$\begin{array}{l}\text { Poblacion } \\
\text { on } 1950 \\
\text { s8) }\end{array}$} & \multicolumn{2}{|c|}{$\begin{array}{l}\text { Tusa amial do } \\
\text { crecimiento }\end{array}$} \\
\hline & & & Total & $\begin{array}{c}\text { Dobido a } \\
\text { nigraoibn } \\
\text { neta }\end{array}$ \\
\hline 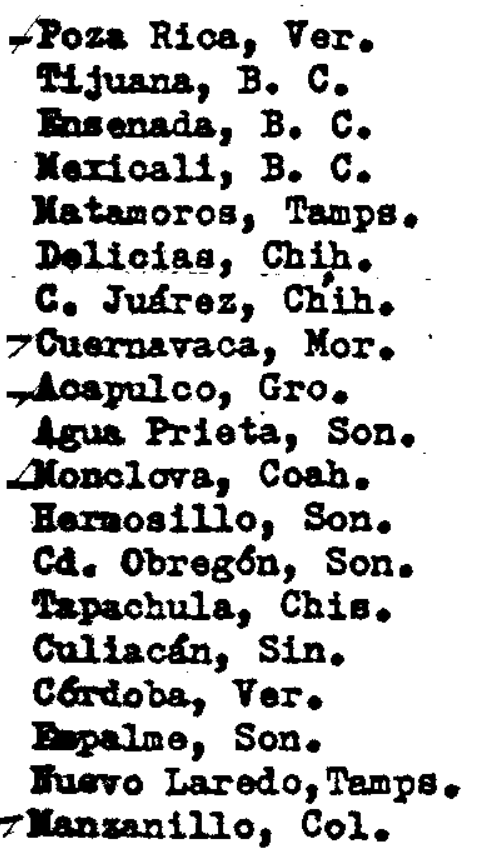 & $\begin{array}{r}4.0 \\
17.0 \\
4.0 \\
19.0 \\
15.7 \\
6.0 \\
49.0 \\
14.3 \\
10.0 \\
4.1 \\
7.0 \\
18.6 \\
12.5 \\
15.2 \\
22.0 \\
17.9 \\
8.8 \\
28.9 \\
6.8\end{array}$ & $\begin{array}{r}14.9 \\
60.0 \\
14.9 \\
65.0 \\
45.8 \\
18.0 \\
123.0 \\
30.6 \\
28.5 \\
10.5 \\
19.0 \\
43.5 \\
31.0 \\
30.0 \\
48.9 \\
32.9 \\
19.9 \\
57.7 \\
13.0\end{array}$ & $\begin{array}{r}11.3 \\
11.4 \\
12.3 \\
11.0 \\
9.8 \\
10.1 \\
8.6 \\
8.1 \\
9.6 \\
8.7 \\
9.1 \\
8.0 \\
8.5 \\
6.6 \\
7.6 \\
5.9 \\
7.5 \\
6.7 \\
6.2\end{array}$ & $\begin{array}{l}9.4 \\
9.1 \\
8.6 \\
8.3 \\
7.4 \\
6.8 \\
6.7 \\
6.2 \\
6.2 \\
6.2 \\
5.8 \\
5.1 \\
5.1 \\
5.1 \\
5.0 \\
5.0 \\
4.7 \\
4.6 \\
4.2\end{array}$ \\
\hline
\end{tabular}

Fuente: Luis Unikel, "El proceso de urbanización en México", en DeMocrafta Y EConomfa, Vol. II, Núm. 2, El Colegio de México, México, 1968.

114están localizadas en importantes regiones agrícolas de las cuales 9 se ubican en el Norte, una en Veracruz y otra en Chiapas. En ellas se cultivan productos de alto valor, principalmente para exportación, cuentan con importantes obras de riego, el financiamiento zropecuario ha sido amplio y el desarrollo tecnológico rápido. Er 2 gudades se desarrollaron industrias básicas: en Monclova la siderurgica y en Poza Rica la petrolera. Dos son puertos turísticos y comerciales

13 Luis Unikel, "El proceso de urbanización en México", DEMOGRafta y EConomf, Vol. II, Núm. 2, El Colegio de México, 1968. 
Cuadro 14

MÉxico: Ciudades de MÁs alto rechazo, 1940-1950

\begin{tabular}{|c|c|c|c|c|}
\hline \multirow{2}{*}{ Ciudad } & \multirow{2}{*}{$\begin{array}{c}\text { Poblacion } \\
\text { en } 1940 \\
=\text { (mil }\end{array}$} & \multirow{2}{*}{$\begin{array}{l}\text { Poblacion } \\
\text { en } 1950 \\
\text { es) }\end{array}$} & \multicolumn{2}{|c|}{$\begin{array}{l}\text { Tasa anual de } \\
\text { crecimiento }\end{array}$} \\
\hline & & & - Total & $\begin{array}{l}\text { Debido a } \\
\text { migracion } \\
\text { neta }\end{array}$ \\
\hline $\begin{array}{l}\text { Autlán, Jal. } \\
\text { Lagos de Moreno, Jal. } \\
\text { La Barca, Jal. } \\
\text { Sahuayo, Mich. } \\
\text { Atlixco, Pue. } \\
\text { Matehuala, S. L. P. } \\
\text { Guanajuato, Gto. }\end{array}$ & $\begin{array}{l}10.9 \\
12.5 \\
13.0 \\
10.5 \\
17.0 \\
16.5 \\
23.5\end{array}$ & $\begin{array}{l}11.3 \\
13.2 \\
14.0 \\
12.5 \\
15.6 \\
14.1 \\
23.4\end{array}$ & $\begin{array}{r}0.39 \\
0.54 \\
0.32 \\
1.78 \\
-0.87 \\
-1.55 \\
-0.06\end{array}$ & $\begin{array}{l}-2.53 \\
-2.84 \\
-2.93 \\
-2.35 \\
-2.33 \\
-4.09 \\
-2.10\end{array}$ \\
\hline
\end{tabular}

Fuente: Unikel, op. cit.

-Acapulco y Manzanillo- y la otra, Cuernavaca, es una ciudad de gran actividad comercial, turística y centro de una importante región agrícola.

El cuadro 14 muestra las ciudades de más alto rechazo (tasa negativa de crecimiento netof.

De estas 7 localidade 4 orresponden a típicas economías rurales, de actividades poco diversificadas y ubicadas en zonas de alta densidad demográfica. Atlixco, que había sido importante centro textil, continuó su decadencia industrial y Guanajuato y Matehuala que-habían sido grandes centros mineros en el pasado - sobre todo el primero- bajaron sensiblemente su actividad productora por la constante elevación de sus costos de explotación frente a precios descen. dentes.

Otras ciudades atrajeron población durante 1940-1950 (tasa anual de crecimiento por migración neta de 1 a $4 \%$ ). En ellas no había un factor evidente de atracción, dado que en general no representaban en aquella década importantes centros de economías regionales, sino antes bien, estaban ubicadas en áreas económicamente deprimidas - decadentes, en entidades de precario nivel de vida. Sin dejar de correr cierto riesgo, pudiera afirmarse que estas ciudades crecieron más por el efecto de repulsión del medio ambiente rural que las ro deaba, que por una creciente actividad económica urbana (véase el -euadro. 15).

3. Situación económica y social de las entidades federativas en 1950

Según los datos que hemos venido considerando, en 1950 el producto bruto per capita -a precios de 1960 - ascendía a 3340.85 pesos, habiendo crecido a razón de $4 \%$ anual, en promedio, durante la dé- 
Cuadro 15

Méxioo: Ciudades con importantes tasas de crecimitento DEBIDO AL. RECHAZO RURAL, 1940-1950

\begin{tabular}{|c|c|c|c|c|}
\hline \multirow[t]{2}{*}{ Ciudad } & \multirow{2}{*}{$\begin{array}{l}\text { Población } \\
\text { on } 1940\end{array}$} & \multirow{2}{*}{$\begin{array}{l}\text { Poblacion } \\
\text { en } 1950 \\
\text { 8) }\end{array}$} & \multicolumn{2}{|c|}{$\begin{array}{l}\text { Tasa anual de } \\
\text { orecimiento }\end{array}$} \\
\hline & & & Total & $\begin{array}{c}\text { Debido a } \\
\text { migractón } \\
\text { neta }\end{array}$ \\
\hline $\begin{array}{l}\text { Sen Prancisco del } \\
\text { Rincón, Gto. } \\
\text { Chilpancingo, Gro.' } \\
\text { Iguala, Gro. } \\
\text { Tesiutín, Puo. } \\
\text { San Luis Potosl, S.I.P. } \\
\text { Apizaoo, Tlaro. } \\
\text { Merida, Iuc. }\end{array}$ & $\begin{array}{r}12.1 \\
8.8 \\
12.8 \\
8.4 \\
77.2 \\
6.8 \\
96.9\end{array}$ & $\begin{array}{r}18.2 \\
12.7 \\
19.4 \\
13.5 \\
125.7 \\
12.7 \\
142.9\end{array}$ & $\begin{array}{l}4.09 \\
3.57 \\
4.14 \\
4.70 \\
4.48 \\
6.10 \\
3.84\end{array}$ & $\begin{array}{l}1.1 \\
1.9 \\
1.6 \\
3.2 \\
2.6 \\
3.2 \\
1.9\end{array}$ \\
\hline
\end{tabular}

Fuente: Unikel, op. cit.

cada 1940-1950. Las 10 entidades de mayor producto per capita en 1950 fueron, en su orden: Baja California Norte, Distrito Federal, Coahuila, Nuevo León, Chihuahua, Tamaulipas, Sonora, Quintana Roó Veracruz y Baja California Sur. Las entidades que mejoraron surposición, respecto a la que tenían en 1940 fueron: Nuevo León, que del 79 lugar pasó a ocupar el 4: en 1950; Tamaulipas que del 8: lugar pasó al 69 y Coahuila que del 4\% pasó al 39. En cambio, perdieron puntos Quintana Roo, que del 3 cayó al 8, Durango y Campeche que dejaron de pertenecer al grupo de los 10 más altos y Sonora que del 6: lugar pasó al 79. Ingresaron al grupo de los 10 Veracruz y Baja California Sur.

- Las entidades de menor producto per capita en 1950 continuaron siendo: Oaxaca ( $20 \%$ del promedio nacional), Chiapas, Guerrero, Ta- basco, Hidalgo, Michoacán y Tlaxcala.

Como puede apreciarse en el cuadro 4, hubo $\not \hat{~ e n t i d a d e s ~ c u y a ~ t a s a ~}$ de producto per capita fue negativa: Quintana Roo, Aguascalientes, Hidalgo, Colima y Nayarit.

En general, puede decirse que en esta década de rápido crecimiento económico, las diferencias entre los estados más desarrollados y los de menor desarrollo relativo, disminuyeron, aunque muy levemente. De las 10 entidades con más alto nivel, en 6 de ellas el producto per capita se incrementó a tasa superior a la media nacional. Por otro lado, de 11 entidades de más bajo producto por habitante, en 8 de ellas la tasa de incremento de 1940 a 1950 fue inferior a la media del país. Utilizando un índice de dispersión éste descendió de .91 en 1940 a .81 en 1950.14

14 El descenso de las disparidades económicas entre entidades federativas del país - sobre la base del producto bruto per capita- refleja que el desarrollo económico tiende a ser cada vez más equilibrado. Esto no implica que si tomára. mos otras unidades territoriales -entidades municipales- el índice de dispersión 
De las entidades de mayor crecimiento económico durante la década, tres de ellas -Estado de México, Veracruz y Tamaulipas- se apoyaron tanto en el aumento de la producción agropecuaria como en la industrial; Baja California y Sinaloa en crecimientos sustanciales de sus actividades terciarias y primarias; Guerrero y Nuevo León en las industrias y los servicios; Baja California Norte y Oaxaca en las actividades industriales y San Luis Potosí casi exclusivamente en los servicios.

O sea que desde el punto de vista estatal, en la mayoría de los casos donde se experimentó una tasa elevada de ćrecimiento econó mico, estuvieron presentes el sector agropecuario y/o el sector de los servicios.

De las entidades cuya tasa del producto per capita fue negativa, en tres de ellas - Colima, Hidalgo y Nayarit - se dio cierto retroceso estructural al incrementarse la participación del sector agropecuario en el producto bruto estatal. Esto se confirma por el hecho de que las entidades con mayor proporción de fuerza de trabajo en el sector primario son precisamente las de más bajo producto per capita y viceversa, y las entidades con mayor proporción de su fuerza de trabajo en los servicios o en las industrias son las de tasa de desarrollo más acelerada y más alto nivel del producto per capita. Para mayor claridad, compárense los cuadros 4 y 16.

En cuanto al nivel de bienestar de las entidades medido a través del índice elaborado, cabe hacer notar que la correlación de rangos entre este índice y el producto per capita de las entidades es menor (.799) que en 1940 (.866). Sin embargo, sigue siendo alta y explicativa del nivel de desarrollo socioeconómico de las entidades. (Véase el cuadro 9.)

El nivel de bienestar del país ascendió 8.5 puntos de 1940 a 1950. Las entidades que elevaron su nivel por encima de este ascenso medio, fueron: Guerrero, Oaxaca, Tabasco, Quinta Roo, Sonora, Coahuila, Morelos y Michoacán. A pesar de ello algunas de estas entidades se mantuvieron a muy bajos niveles, debido a que desde 1940 guardaban una muy desventajosa posición. Coahuila y Morelos mejoraron su po-

pudiera dar resultados diferentes. Sin embargo, nada puede adelantarse mientras no se tengan los datos disponibles.

La fórmula para el índice de dispersión se temó de Jeffrey G. Williamson, "Regional Inequality and the Process of National Development: a Description of the Patterns", Economic Development and Cultural Change, Vol. XIII, Núm. 4, julio de 1965 ; la fórmula es la siguiente:

$$
I_{d}=\frac{\sqrt{\frac{\sum_{i}^{n}\left(Y_{i}-\bar{Y}\right)^{2}}{n}}}{\bar{Y}}
$$

donde: $Y_{i}=$ ingreso per capita en el $i$-ésimo estado

$\overline{\mathbf{Y}}=$ ingreso per capita medio, nacional

$\boldsymbol{n}=$ número de entidades 
Cuadro 16 (conclusión)

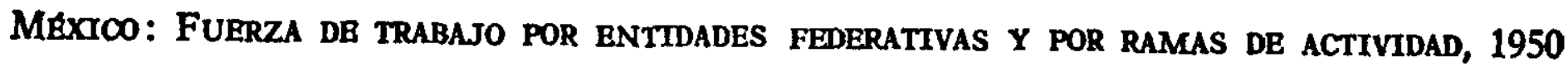
(Porcientos del total)

\begin{tabular}{|c|c|c|c|c|c|c|c|c|c|c|}
\hline \multirow[b]{2}{*}{ motided } & \multirow[b]{2}{*}{$\begin{array}{l}\text { Potal } \\
\text { Puerza } \\
\text { de tra } \\
\text { bajo }\end{array}$} & \multirow{2}{*}{$\begin{array}{l}\text { Agrioul- } \\
\text { tura, ge } \\
\text { nadoriag } \\
\text { oilvicul } \\
\text { tera, og } \\
\text { ea jo pon } \\
\text { cas }\end{array}$} & \multicolumn{4}{|c|}{ INDUSTRIAS } & \multirow[b]{2}{*}{ Comerole } & \multirow[b]{2}{*}{$\underset{\text { tee }}{\text { TranepoI }}$} & \multirow[b]{2}{*}{ Dexviolos } & \multirow{2}{*}{$\begin{array}{l}\text { Aotivide } \\
\text { dee inny } \\
\text { eloionte } \\
\text { mente of } \\
\text { pooirlos } \\
\text { das }\end{array}$} \\
\hline & & & $\underset{\text { vas }}{\text { Extreoti }}$ & $\begin{array}{l}\text { De Trane } \\
\text { Cormaotón }\end{array}$ & $\begin{array}{c}\text { Construg } \\
\text { ofion }\end{array}$ & $\begin{array}{l}\text { Elootrlo1- } \\
\text { ded, gall, } \\
\text { oto. }\end{array}$ & & & & \\
\hline Ropúblion & 100.0 & 58.3 & 1.2 & 11.8 & 2.7 & 0.3 & 8.3 & 2.5 & 10,6 & 4.3 \\
\hline 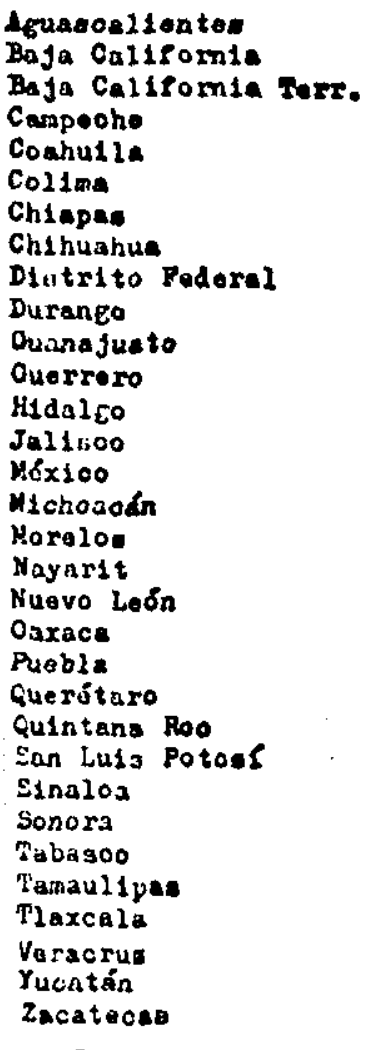 & $\begin{array}{l}100.0 \\
100.0 \\
100.0 \\
100.0 \\
100.0 \\
100.0 \\
100.0 \\
100.0 \\
100.0 \\
100.0 \\
100.0 \\
100.0 \\
100.0 \\
100.0 \\
100.0 \\
100.0 \\
100.0 \\
100.0 \\
100.0 \\
100.0 \\
100.0 \\
100.0 \\
100.0 \\
100.0 \\
100.0 \\
100.0 \\
100.0 \\
100.0 \\
100.0 \\
100.0 \\
100.0 \\
100.0\end{array}$ & $\begin{array}{l}50.6 \\
45.6 \\
51.7 \\
57.4 \\
49.2 \\
59.1 \\
78.5 \\
55.0 \\
4.7 \\
70.9 \\
67.1 \\
80.7 \\
71.4 \\
58.8 \\
73.5 \\
73.4 \\
67.0 \\
69.9 \\
41.0 \\
78.1 \\
67.2 \\
70.3 \\
63.8 \\
68.9 \\
67.6 \\
54.4 \\
75.9 \\
52.6 \\
70.3 \\
66.9 \\
59.8 \\
78.8\end{array}$ & $\begin{array}{l}0.4 \\
0.5 \\
0.6 \\
0.4 \\
4.0 \\
0.3 \\
0.3 \\
4.7 \\
0.5 \\
2.4 \\
0.9 \\
0.6 \\
2.4 \\
0.3 \\
0.6 \\
0.6 \\
0.2 \\
0.3 \\
0.8 \\
0.4 \\
0.4 \\
0.3 \\
0.1 \\
2.0 \\
c .5 \\
2.8 \\
0.5 \\
3.6 \\
0.1 \\
1.6 \\
0.2 \\
3.4\end{array}$ & $\begin{array}{r}14.7 \\
11.1 \\
7.8 \\
14.1 \\
13.2 \\
9.2 \\
5.7 \\
9.2 \\
26.1 \\
7.2 \\
13.0 \\
6.1 \\
7.5 \\
12.8 \\
8.2 \\
8.0 \\
6.8 \\
7.2 \\
18.4 \\
9.7 \\
11.7 \\
9.4 \\
8.4 \\
8.3 \\
7.5 \\
8.4 \\
5.2 \\
8.4 \\
12.1 \\
8.2 \\
11.8 \\
4.5\end{array}$ & $\begin{array}{l}3.2 \\
4.1 \\
2.9 \\
3.3 \\
3.4 \\
2.8 \\
1.6 \\
3.7 \\
5.7 \\
1.8 \\
1.8 \\
1.0 \\
1.7 \\
3.2 \\
1.8 \\
1.8 \\
2.7 \\
2.4 \\
4.1 \\
1.1 \\
1.8 \\
1.8 \\
1.4 \\
2.0 \\
2.0 \\
4.5 \\
1.6 \\
3.0 \\
2.2 \\
2.0 \\
3.2 \\
1.3\end{array}$ & $\begin{array}{l}0.4 \\
0.5 \\
0.3 \\
0.2 \\
0.4 \\
0.3 \\
0.1 \\
0.3 \\
0.7 \\
0.2 \\
0.2 \\
0.1 \\
0.2 \\
0.3 \\
0.4 \\
0.2 \\
0.3 \\
0.2 \\
0.3 \\
0.1 \\
0.3 \\
0.2 \\
0.1 \\
0.2 \\
0.2 \\
0.3 \\
0.1 \\
0.4 \\
0.1 \\
0.2 \\
0.3 \\
0.2\end{array}$ & $\begin{array}{r}10.7 \\
11.7 \\
5.6 \\
7.7 \\
10.0 \\
8.2 \\
4.6 \\
8.0 \\
17.1 \\
5.7 \\
7.0 \\
3.6 \\
6.0 \\
8.8 \\
5.8 \\
6.7 \\
7.3 \\
6.7 \\
11.2 \\
3.6 \\
7.0 \\
6.3 \\
5.5 \\
6.7 \\
6.9 \\
8.5 \\
4.7 \\
10.6 \\
4.6 \\
7.0 \\
9.5 \\
4.2\end{array}$ & $\begin{array}{l}6.0 \\
3.0 \\
3.1 \\
4.3 \\
3.7 \\
3.2 \\
1.1 \\
3.1 \\
5.5 \\
2.1 \\
1.7 \\
0.8 \\
1.2 \\
2.4 \\
1.3 \\
1.4 \\
1.9 \\
2.0 \\
3.9 \\
0.8 \\
1.7 \\
1.2 \\
3.3 \\
2.4 \\
2.6 \\
4.1 \\
1.7 \\
3.7 \\
2.1 \\
2.4 \\
3.0 \\
0.9\end{array}$ & $\begin{array}{r}10.2 \\
17.3 \\
16.9 \\
.9 .0 \\
10.4 \\
14.8 \\
6.5 \\
10.9 \\
30.4 \\
6.8 \\
5.5 \\
5.2 \\
7.4 \\
9.1 \\
5.4 \\
5.4 \\
9.3 \\
7.9 \\
11.0 \\
4.7 \\
6.9 \\
7.0 \\
15.5 \\
6.6 \\
8.2 \\
12.0 \\
7.3 \\
11.7 \\
5.4 \\
7.8 \\
8.5 \\
4.4\end{array}$ & $\begin{array}{l}3.8 \\
6.2 \\
3.1 \\
3.6 \\
5.7 \\
2.1 \\
1.6 \\
5.1 \\
3.3 \\
2.9 \\
2.8 \\
1.9 \\
2.2 \\
4.3 \\
3.0 \\
2.5 \\
4.5 \\
2.4 \\
9.3 \\
1.5 \\
3.0 \\
3.5 \\
1.9 \\
2.9 \\
4.5 \\
5.0 \\
3.0 \\
6.0 \\
3.1 \\
3.9 \\
3.7 \\
2.3\end{array}$ \\
\hline Complenuntarios & 100.0 & 3.2 & 0.3 & 11.6 & 5.6 & 0.2 & 14.6 & 7.4 & 52.6 & $4.5^{\circ}$ \\
\hline
\end{tabular}

Fuente: VII Censo General de Población, 1950. 
Cuadro 16

México: Fuerza de tRabajo pOR eNTTDADES FEDERATIVAS Y POR RAMAS de ACTIVIDAd, 1950

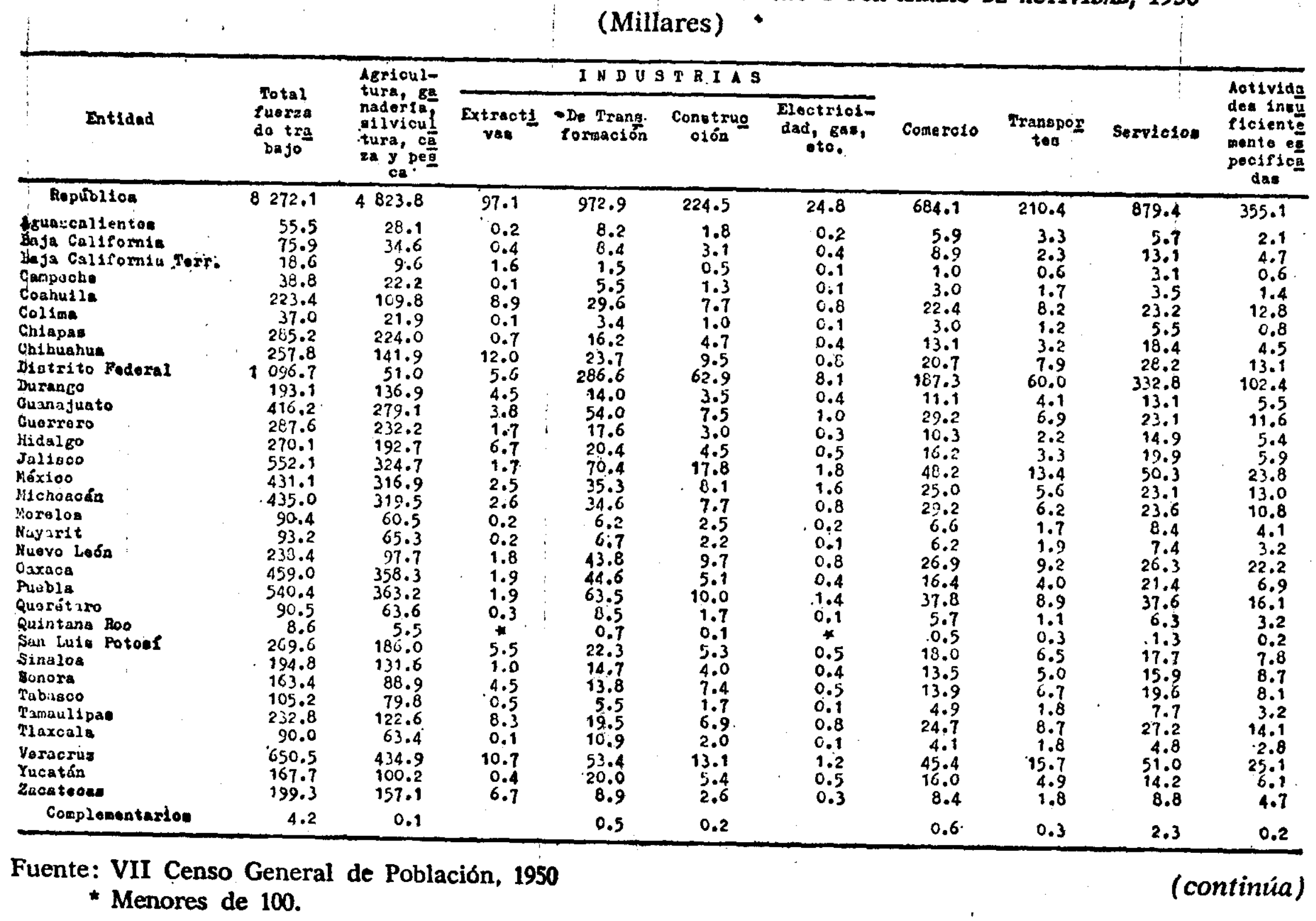


sición relativa, pero Aguascalientes, Nayarit, Zacatecas y Tlaxcala la empeoraron.

Un caso que es necesario mencionar de manera especial es el del Estade de Baja California. No obstante que durante la década su producto per capita creció a tasa de $5 \%$ anual, en promedio, su nivel de bienestar creció mucho menos que el ascenso promedio registrado en el país. Es probable que debido a su muy alta tasa de inmigración - concentrada principalmente en Tijuana, Ensenada y Mexicali- haya recibido una gran proporción de población rural de otras regiones del país, de muy bajos niveles sociales y diferentes patrones de vida, lo que originó este lento proceso de desarrollo social de 1940 a 1950.

\section{De 1950 a 1960}

Este decenio representa no sólo uno de los períodos más dinámicos de la historia económica del país, sino que además fue en esta etapa cuando se establecieron las bases que sirvieron para consolidar la economía nacional. El producto bruto creció a $6.1 \%$ anual en promedio, y las manufacturas, el petróleo y la construcción lo hicieron casi al $8 \%$; la energía eléctrica desarrolló su producto a tasa cercana al $9.3 \%$; en cambio la agricultura creció apenas al $4.4 \%$.

A principios del decenio se presentó una notable baja en la demanda externa debido a un receso de la economía norteamericana -nuestro principal cliente- y a la terminación de la guerra de Corea; por otra parte, continuaba alta la propensión a importar, lo que originó que en 1954 se devaluara el peso mexicano en $48 \%$; a partir de entonces se aprovechó la coyuntura para desarrollar la economía "hacia adentro".,

Las industrias que más se desarrollaron fueron: química, construcción de maquinaria, siderúrgica y metálica, equipo de transporte y hule. Las actividades que se desenvolvieron más lentamente fueron: textiles, calzado, prendas de vestir, madera y productos de cuero.

De los minerales que México ha producido tradicionalmente, todos, excepto el zinc, el hierro y el mercurio descendieron notablemente de 1950 a 1960 ; el oro descendió $24 \%$; la plata, $11.6 \%$; el plomo, $19 \%$.

Si en el pasado se había dado mayor énfasis a la agricultura de exportación, en el decenio 1950-1960 el esfuerzo fue más equilibrado, aumentando los productos agrícolas de alimentación básica -maíz, frijo, trigo, cebolla, lenteja, tomate, avena y arroz. Los vinculados al comérçio exterior que continuaron incrementándose fueron: algodón, caña de azúcar y café. En este decenio el henequén pasó por una de. sus peores épocas, pero comenzó a recuperarse en 1954 hasta llegar en 1960 a los más altos nivelés de prođucción.

Los precios de la agricultura evolucionāron más lentamente que en la industria, y más aún que en los servicios; además, la productividad por hombre en la agricultura creció mạ́s lentamente que en los otros sectores, razón por la cual puede afirmarse que aumentaron, los desequilibrios sociales. La productividad agrícola cręció más rápidamente en el Pacífico Norte y de manera más lenta en el " 'fo y en el Centro. 
Los estados del Norte obtuvieron mayor producto agropecuario per capita que los del resto del país. Veracruz hizo importantes contribuciones en café, tabaco, caña de azúcar y frijol; Yucatán produjo el $90 \%$ del henequén nacional; en Sonora tuvo importancia el trigo, en Sinaloa el tomate y en ambos el arroz; en el Estado de Baja California, el algodón; en Chiapas el cacao, en Oaxaca el tabaco y en ambos el café; en Jalisco, el maíz; en Tepic, el tabaco y la caña de azúcar. Todas estas entidades destacaron agrícolamente durante el decenio 1950-1960.

El proceso de industrialización continuó centralizándose en el Distrito Federal, en el Estado de México (ahora no solamente los municipios aledaños al Distrito Federal, sino que Toluca surgió ya como ciudad industrial) y en el Estado de Nuevo León. Según cálculos de Erik Bennewitz, de las inversiones industriales efectuadas de 1950 a 1960, el $49.6 \%$ correspondió al Distrito Federal, $12.9 \%$ al Estado de México y $11.1 \%$ al de Nuevo León. Del aumento neto en la producción industrial, el $51.3 \%$ correspondió al Distrito Federal, 15.3\% al Estado de México y $11.8 \%$ a Nuevo León.

Por otra parte y de acuerdo con los datos de los censos industriales, el $92.5 \%$ de los nuevos empleos en la industria (excluyendo al petróleo) fueron creados en el Distrito Federal, Estado de México y Nuevo León, siendo el Distrito Federal el máximo creador de empleo industrial con $83 \%$.

VI. El PROCESO de URBANIZACIÓN Y LAS ECONOMfaS REGIONALES, 1950-1960

En este período puede identificarse con mayor claridad la función que algunas grandes ciudades asumen como polos regionales de crecimiento, así como el nacimiento de nuevas concentraciones urbanas

Cuadro 17

México: Ciudades de altas tasas de crectmiento debido A MIGRACIONES NETAS, $1950-1960$

\begin{tabular}{|c|c|c|c|c|}
\hline \multirow[b]{2}{*}{ Ciudad } & $\begin{array}{l}\text { Poblacion } \\
\text { en } 1950\end{array}$ & \multirow{2}{*}{$\begin{array}{c}\text { Población } \\
\text { en } 1960\end{array}$} & \multicolumn{2}{|c|}{$\begin{array}{l}\text { Tasa anual de } \\
\text { crecimiento }\end{array}$} \\
\hline & $\begin{array}{r}\text { en } 1950 \\
\text { (mi }\end{array}$ & & Total & $\begin{array}{l}\text { Debido a } \\
\text { migracior } \\
\text { neta }\end{array}$ \\
\hline $\begin{array}{l}\text { Bnsenada, B. C. } \\
\text { Mexicali, B. C. } \\
\text { Tijuana, B. C. } \\
\text { Monclova, Coah. } \\
\text { C. Juarez, Chih. } \\
\text { Delicias, Chih. } \\
\text { Apatzingan, Nich. } \\
\text { San Luis Rlo Colorado, Son. }\end{array}$ & $\begin{array}{r}18.0 \\
65.0 \\
60.0 \\
19.0 \\
123.0 \\
18.0 \\
8.0 \\
4.0\end{array}$ & $\begin{array}{r}42.0 \\
175.0 \\
152.0 \\
43.0 \\
262.0 \\
40.0 \\
20.0 \\
29.0\end{array}$ & $\begin{array}{l}8.0 \\
9.1 \\
8.7 \\
5.5 \\
7.2 \\
7.4 \\
8.0 \\
15.0\end{array}$ & $\begin{array}{l}4 \cdot 5 \\
4.9 \\
4 \cdot 8 \\
4 \cdot 2 \\
4.4 \\
4 \cdot 3 \\
5.3 \\
10.2\end{array}$ \\
\hline
\end{tabular}

Fuente: Unikel, op. cit. 
con similar función. Dentro de estas últimas cabe mencionar las ciudades de más rápido crecimiento durante la década. (Véase el cuadro 17.)

Estas localidades continuaron su desarrollo apoyadas principalmente en la agricultura comercial de exportación -excepto Monclova, centro siderúrgico- y en las actividades terciarias; es interesante anotar el proceso de diversificación de las actividades económicas de estas ciudades, a medida que aceleran su proceso de crecimiento.

El aumento de la población llegó a ser aún más rápido en algunas ciudades incluidas en el grupo 1 del cuadro 18. Tecomán y Navojoa crecieron como centros de regiones agropecuarias ricas en cultivos de altos beneficios; en Mazatlán se desarrolló la actividad comercial portuaria, el turìsmo y la pesca, y en Minatitlán se desarrolló una muy dinámica actividad petrolera.

\section{Cuadro 18}

México: Población y tasa aNual de CRecimiento de algunas CIUdAdes, 1940-1960

\begin{tabular}{|c|c|c|c|c|c|c|c|}
\hline \multirow[t]{2}{*}{ Cludader } & \multicolumn{3}{|c|}{ Población } & \multicolumn{2}{|c|}{$\begin{array}{l}\text { Tasa anual d } \\
\text { Total }\end{array}$} & \multicolumn{2}{|c|}{$\begin{array}{c}\text { creciniento } \\
\text { Debido a gi- } \\
\text { Bracion Rota }\end{array}$} \\
\hline & 1940 & $\frac{1950}{1,000}$ & 1960 & $940 / 50$ & $1950 / 60$ & $1940 / 50$ & $195 \mathrm{C} / 60$ \\
\hline 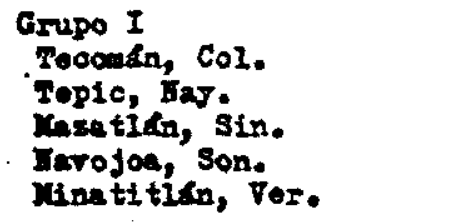 & $\begin{array}{r}3.3 \\
17.5 \\
32.1 \\
11.0 \\
18.5\end{array}$ & $\begin{array}{r}7.2 \\
24.6 \\
41.8 \\
17.3 \\
22.5\end{array}$ & $\begin{array}{l}16.2 \\
54.0 \\
75.8 \\
30.6 \\
35.4\end{array}$ & $\begin{array}{l}7.5 \\
3.3 \\
2.6 \\
4.5 \\
1.9\end{array}$ & $\begin{array}{l}7.7 \\
7.5 \\
5.8 \\
5.5 \\
4.5\end{array}$ & $\begin{array}{l}1.7 \\
0.8 \\
0.6 \\
1.3 \\
0.1\end{array}$ & $\begin{array}{l}4.5 \\
4.2 \\
3.0 \\
1.8 \\
1.7\end{array}$ \\
\hline 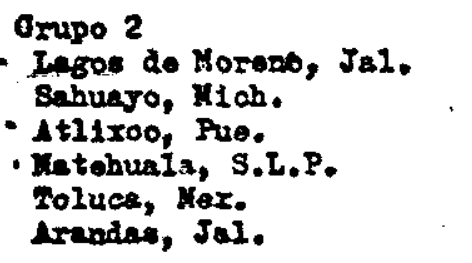 & $\begin{array}{l}12.5 \\
10.5 \\
17.0 \\
16.5 \\
43.4 \\
7.3\end{array}$ & $\begin{array}{r}13.2 \\
12.5 \\
15.6 \\
14.1 \\
53.0 \\
9.3\end{array}$ & $\begin{array}{l}23.6 \\
25.7 \\
30.6 \\
19.9 \\
77.1 \\
17.1\end{array}$ & $\begin{array}{r}0.5 \\
1.8 \\
-0.9 \\
-1.6 \\
2.0 \\
2.5\end{array}$ & $\begin{array}{l}5.7 \\
6.9 \\
6.5 \\
3.4 \\
4.1 \\
5.9\end{array}$ & $\begin{array}{l}-2.8 \\
-2.4 \\
=2.3 \\
=4.1 \\
=0.4 \\
-1.1\end{array}$ & $\begin{array}{l}1.7 \\
2.3 \\
3.8 \\
0.9 \\
1.2 \\
2.6\end{array}$ \\
\hline 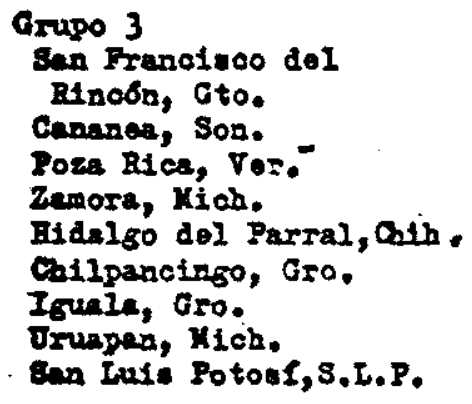 & $\begin{array}{r}12.1 \\
11.0 \\
4.0 \\
15.4 \\
24.2 \\
8.8 \\
12.8 \\
20.6 \\
77.2\end{array}$ & $\begin{array}{r}18.2 \\
17.9 \\
14.9 \\
23.4 \\
32.1 \\
12.7 \\
19.4 \\
31.4 \\
125.7\end{array}$ & $\begin{array}{r}20.1 \\
19.7 \\
19.6 \\
34.4 \\
41.5 \\
18.0 \\
26.8 \\
45.8 \\
160.0\end{array}$ & $\begin{array}{r}4.1 \\
4.8 \\
11.3 \\
5.4 \\
2.8 \\
3.6 \\
4.1 \\
4.2 \\
4.5\end{array}$ & $\begin{array}{l}1.4 \\
1.0 \\
2.7 \\
1.8 \\
2.6 \\
3.5 \\
3.2 \\
3.7 \\
2.4\end{array}$ & $\begin{array}{l}1.1 \\
0.7 \\
9.4 \\
3.2 \\
0.6 \\
1.9 \\
1.6 \\
1.7 \\
2.6\end{array}$ & $\begin{array}{l}-2.3 \\
=2.5 \\
=0.9 \\
=1.8 \\
=0.9 \\
=0.4 \\
=0.1 \\
=0.2 \\
=0.9\end{array}$ \\
\hline 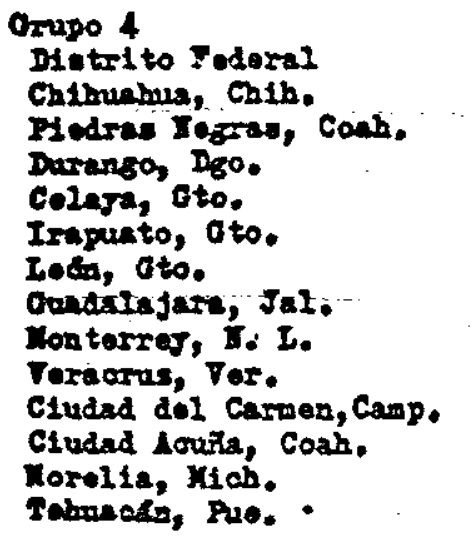 & $\begin{aligned} 1584.6 \\
56.8 \\
15.7 \\
33.4 \\
22.8 \\
32.4 \\
74.2 \\
229.2 \\
186.1 \\
71.7 \\
7.7 \\
5.6 \\
44.3 \\
16.3\end{aligned}$ & $\begin{array}{r}2900.0 \\
87.0 \\
27.6 \\
59.4 \\
34.4 \\
49.4 \\
122.7 \\
377.0 \\
333.4 \\
101.2 \\
11.6 \\
11.4 \\
63.2 \\
23.2\end{array}$ & $\begin{array}{r}4707.2 \\
150.4 \\
45.0 \\
97.3 \\
58.9 \\
83.8 \\
209.9 \\
736.8 \\
569.9 \\
144.7 \\
21.2 \\
20.0 \\
100.8 \\
31.9\end{array}$ & $\begin{array}{l}5.4 \\
4.2 \\
5.5 \\
5.6 \\
4.1 \\
4.2 \\
4.9 \\
4.9 \\
5.9 \\
3.4 \\
4.1 \\
6.8 \\
3.6 \\
3.5\end{array}$ & $\begin{array}{l}4.6 \\
5.7 \\
4.8 \\
4.7 \\
5.2 \\
5.2 \\
5.2 \\
6.4 \\
6.3 \\
3.7 \\
5.8 \\
5.5 \\
4.7 \\
3.2\end{array}$ & $\begin{array}{l}3.7 \\
2.0 \\
2.8 \\
3.2 \\
1.2 \\
1.2 \\
2.0 \\
3.0 \\
3.6 \\
2.3 \\
1.5 \\
4.0 \\
2.0 \\
2.6\end{array}$ & $\begin{array}{l}1.5 \\
2.8 \\
1.7 \\
1.4 \\
3.0 \\
1.7 \\
2.2 \\
3.7 \\
3.3 \\
2.1 \\
2.0 \\
2.3 \\
1.7 \\
1.1\end{array}$ \\
\hline
\end{tabular}




\section{Cuadro 18 (conclusión)}

\begin{tabular}{|c|c|c|c|c|c|c|c|}
\hline $\begin{array}{l}\text { Lon Kochis, Sir. } \\
\text { Togales, Son. } \\
\text { Tille Bormoss, Tab. } \\
\text { Cludud Viatoris, Teupa. } \\
\text { Costracoslcos, Vor. }\end{array}$ & $\begin{array}{l}12.9 \\
13.9 \\
25.6 \\
19.5 \\
13.1\end{array}$ & $\begin{array}{l}21.6 \\
24.5 \\
35.4 \\
31.8 \\
19.5\end{array}$ & $\begin{array}{l}38.3 \\
37.7 \\
55.4 \\
50.8 \\
37.3\end{array}$ & $\begin{array}{l}5.0 \\
5.5 \\
3.2 \\
4.8 \\
3.8\end{array}$ & $\begin{array}{l}5.6 \\
4.2 \\
4.4 \\
4.6 \\
6.4\end{array}$ & $\begin{array}{l}1.7 \\
3.0 \\
1.3 \\
1.9 \\
2.3\end{array}$ & $\begin{array}{l}1.9 \\
0.8 \\
1.6 \\
1.5 \\
3.6\end{array}$ \\
\hline 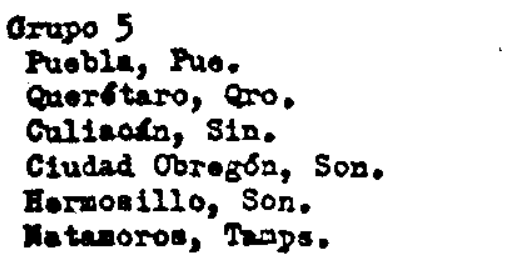 & $\begin{array}{r}138.5 \\
33.6 \\
22.0 \\
12.5 \\
18.6 \\
15.7\end{array}$ & $\begin{array}{r}211.3 \\
49.2 \\
48.9 \\
31.0 \\
43.5 \\
45.8\end{array}$ & $\begin{array}{r}289.1 \\
67.7 \\
85.0 \\
68.0 \\
96.0 \\
92.3\end{array}$ & $\begin{array}{l}4.5 \\
3.8 \\
7.6 \\
8.5 \\
8.0 \\
9.8\end{array}$ & $\begin{array}{l}2.6 \\
3.1 \\
5.4 \\
7.5 \\
7.5 \\
6.7\end{array}$ & $\begin{array}{l}3.6 \\
1.7 \\
5.0 \\
5.1 \\
5.1 \\
7.4\end{array}$ & $\begin{array}{l}0.8 \\
0.4 \\
1.5 \\
3.2 \\
3.6 \\
2.8\end{array}$ \\
\hline 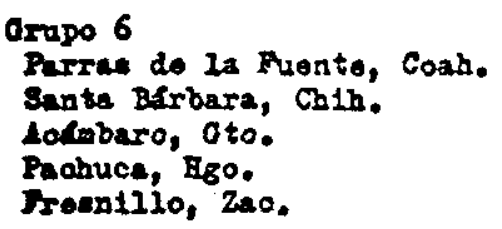 & $\begin{array}{l}15.6 \\
13.9 \\
17.6 \\
53.4 \\
24.6\end{array}$ & $\begin{array}{l}18.5 \\
14.9 \\
23.0 \\
58.7 \\
30.0\end{array}$ & $\begin{array}{l}19.8 \\
15.8 \\
26.2 \\
64.6 \\
35.6\end{array}$ & $\begin{array}{l}1.8 \\
0.6 \\
2.6 \\
1.0 \\
2.0\end{array}$ & $\begin{array}{l}0.6 \\
0.7 \\
1.3 \\
1.1 \\
1.7\end{array}$ & $\begin{array}{l}=1.6 \\
=1.8 \\
=0.4 \\
=1.7 \\
=1.0\end{array}$ & $\begin{array}{l}-2.6 \\
=2.8 \\
=2.3 \\
-2.2 \\
-2.2\end{array}$ \\
\hline
\end{tabular}

Fuente: Unikel, op. cit.

- Hay un grupo de ciudades que, habiendo sido de rechazo en el decenio 1940-1950, se convirtieron en centros de atracción durante la siguiente década, como es el caso de las incluidas en el grupo 2 del cuadro 18; esto refleja reanimación económica regional debido a nuevas inversiones industriales (Toluca, Atlixco) o la construcción de infraestricturas de desarrollo (Matehuala).

- Hay otras, en cambio, que habiendo sido de atracción durante la década 1940-1950, ya fuera por lo precario de su economía regional (Iguala, Chilpancigo, Zamora), por haber recibido excesiva inmigración durante el decenio anterior (Poza Rica) o por franca decadencia económica (Cananea y Parral), se convirtieron en ciudades de rechazo; éstas son las del grupo 3 , en el cuadro 18.

El grupo 4 se ha formado con ciudades de elevada atracción sostenida a lo largo de los dos decenios. En este grupo, León, Guadalajara, Monterrey y Veracruz siguen siendo ciudades de importante crecimiento industrial, comercial y de servicios. Piedras Negras, Acuña y Nogales crecen como invariablemente lo han hecho todas las ciudades fronterizas con Estados Unidos de América, básicamente por el turismo y el comercio originados por tal vecindad. Irapuato, Celaya y León forman el "corredor industrial del Bajío", junto con Salamanca; esta zona creció rápidamente debido a la ubicación de la refinería de Salamanca, el desarrollo de la infraestructura ragional, la intensificación de la agricultura comercial y su elevado crecimiento demográfico.

- El aumento de población se ha vuelto lento en algunas ciudades, quizá por falta de viabilidad económica. Estas ciudades forman el grupo 5. De ellas, cuatro corresponden a economías regionales basadas en la agricultura comercial que si bien motivó fuerte inmigración en el decenio 1940-1950, en tos siguientes diez años no presentó el mismo ritmo de expansión. $P$ stra parte, la tasa de crecimiento industrial 
desaceleró su ritmo en Puebla y Querétaro, quizá en favor de la más alta concentración en la zona metropolitana de la ciudad de México.

- Por último, tenemos ciudades ubicadas en regiones de economía francamente decadente; casi todas de antigua importancia minera, que representaron regiones y ciudades emergentes cuando la actividad minera asumía el papel de sector estratégico. A estas localidades, que se integran en el grupo 6, deben sumarse algunas incluidas en el grupo 3 (Cananea, Parral, San Luis Potosí), lo que ayudará a tener una idea más clara de este fenómeno.

\section{Situación económica y social de las entidades federativas en 1960}

De 1950 a 1960 el producto per capita del país creció a tasa pro- medio de $3.0 \%$. Las entidades que alcanzaron más altos niveles, fueron: el Distrito Federal, Nuevo León, Baja California Norte, Sonora, Coahuila, Tamaulipas, Chihuahua, Sinaloa, Baja California Sur y

- Campeche. Las entidades que mejoraron su posición respecto de 1950, fueron: el Distrito Federal, Nuevo León, Sonora, Sinaloa -que ingresó al grupo de las 10 de más alto nivel-, Baja California Sur y Campeche; esta última reingresó al grupo al que había pertenecido en 1940. Empeoraron su posición relativa: Baja California Norte, Coahuila, Chihuahua, Veracruz - que salió del grupo de las 10- y Quintana Roo, que no solamente salió del grupo sino que pasó a ocupar el lugar número 27 (de 32) en cuanto a nivel de producto per capita; representa, junto con Zacatecas, el caso más dramático de relativo retroceso económico.

- Las entidades de menor producto per capita eran, en 1960: Oaxaca, Tlaxcala, Zacatecas, Michoacán, Hidalgo, Quintana Roo, Chiapas, Guerrero, Querétaro y Puebla.

A diferencia del proceso de desarrollo regional de la década anterior, de 1950 a 1960 tienden a disminuir más rápidamente las diferencias de nivel de desarrollo entre los estados. De los estados de más alto nivel sólo uno - Nuevo León- formó parte de los que tuvieron la tasa más alta de crecimiento del producto per capita. El índice de dispersión descendió de .81 en 1950 a .58 en 1960.

Otra diferencia del proceso económico regional de la década 1950. 1960 con la anterior, es que las entidades que experimentaron más alta tasa de crecimiento se apoyaron principalmente en la industrialización -Nuevo León, México, Aguascalientes y Nayarit-o aunado a un proceso de "terciarización" de la economía - Guanajuato, Jalisco, Sinaloa, Nayarit y Tabasco-; Sonora y Guerrero se apoyaron en el sector terciario principalmente, y sólo en Chiapas y Oaxaca las actividades ágropecuarias tuvieron cierta aportación de importancia en el ritmo de crecimiento económico. La importancia del sector industrial en este proceso y la escasa participación del sector agropecuario se deriva del tipo de desarrollo del país en esta década; recuérdese que el sector secundario creció al $8 \%$, mientras que el agropecuario apenas logró un $4 \%$ anual, en promedio.

En cuanto al índice de bienestar, ascendió apenas 6.5 puntos, en promedio, durante la década, y las entidades que mejoraron su nivel particular por encima del ascenso medio del país fueron: Nuevo 
León, Campeche, Aguascalientes, Jalisco, Sinaloa, México y Tabasco. Entre las que se desarrollaron por debajo del promedio nacional -en cuanto a índice de bienestar - se contaron: Chiapas, Guerrero, Oaxaca, Hidalgo, Zacatecas y Querétaro, entre otras; se mencionan las anteriores porque son entidades que ya de por sí guardaban una posición desventajosa en cuanto a bienestar. $O$ sea que si, desde el punto de vista estrictamente económico, de 1950 a 1960 las diferencias entre entidades tienden a disminuir, es ẹvidente que en çuanto a situación social las entidades no siguen un patrón similar.

Si analizamos la posición de las entidades con relación al índice de bienestar a lo largo de tres fechas censales, tenemos, entre otros, los siguientes hechos: a) las entidades que mejoraron sustancialmente su posición, fueron: Tabasco, Campeche, Sonora, Jalisco y México, y su mejoramiento se realizó principalmente de 1950 a $1960 ; b$ ) las entidades que perdieron posiciones, fueron: de 1940 a 1950, Tlaxcala; de 1950 a 1960, Colima y Yucatán; la pauperización de Zacatecas fue constante de 1940 a 1960.

Por último, desde el punto de vista demográfico y según puede apreciarse en el cuadro 11, en 1960 el índice de natalidad ascendió a 46.0 en el país, siendo inferior en las 10 entidades de mayor nivel de bienestar (44.9) y mayor en las entidades más atrasadas (47.2). De 1940 a 1960 el índice de natalidad creció $5.75 \%$ a nivel nacional; en cuanto a entidades, en las de más bajo nivel se incrementó casi el doble que en las más desarrolladas. Sin embargo, el índice es una tasa al millar, de tal suerte que las diferencias son mínimas.

Si se recuerdan los componentes del índice de bienestar -población urbana, alfabetizada, que usa calzado, que cuenta con agua y drenaje y que usualmente come pan de trigo-, bien podríamos tomarlo como un índice de modernización y entonces cabría afirmar que hasta ahora el factor modernización no ha influido de manera sensible en las tasas de fecundidad. Desde luego es difícil escapar a la tentación de teorizar sobre los resultados obtenidos, pero es necesario mantener una prudente actitud de reserva hasta que las investigaciones sobre fecundidad rural y urbana nos den mayores elementos para asumir una posición más firme. ${ }^{15}$

En donde es más fácil la inferencia es en el índice de mortalidad general, ya que es claro que en las entidades que más se han urbanizado, en que más ha crecido el producto per capita, los niveles de mortalidad se abatan más rápidamente que en las de mayor atraso y eso es lo que nos indica el cuadro 11. Pero en cuanto a la mortalidad infantil, se mantiene el mismo problema de que el índice es más alto en las entidades de mayor bienestar que en los estados inferiores, lo que seguramente se explica por una falta de captación de los datos estadísticos que precisamente se agudiza, como ya se afirmó antes, en aquellas áreas donde funcionan de manera más precaria las instituciones, la población es más ignorante, está más dispersa en pequeñas localidades rurales, muchas veces de difícil acceso, todo lo cual

15 El Instituto de Invéstigaciones Sociales en la UNAM realizó una investigación sobre fecundidad urbana y conjuntamente con el Centro de Estudios Económicos y Demográficos del Colegio de México se realiza otra sobre fecundidad rural, ambas a cargo de $\hat{\mathbf{R}}$. Benítez Zenteno. 
Cuadro 19 (conclusión)

México: Población económicambnte activa por entidades federativas y ramas de actividad, 1960 (Porcientos del total)

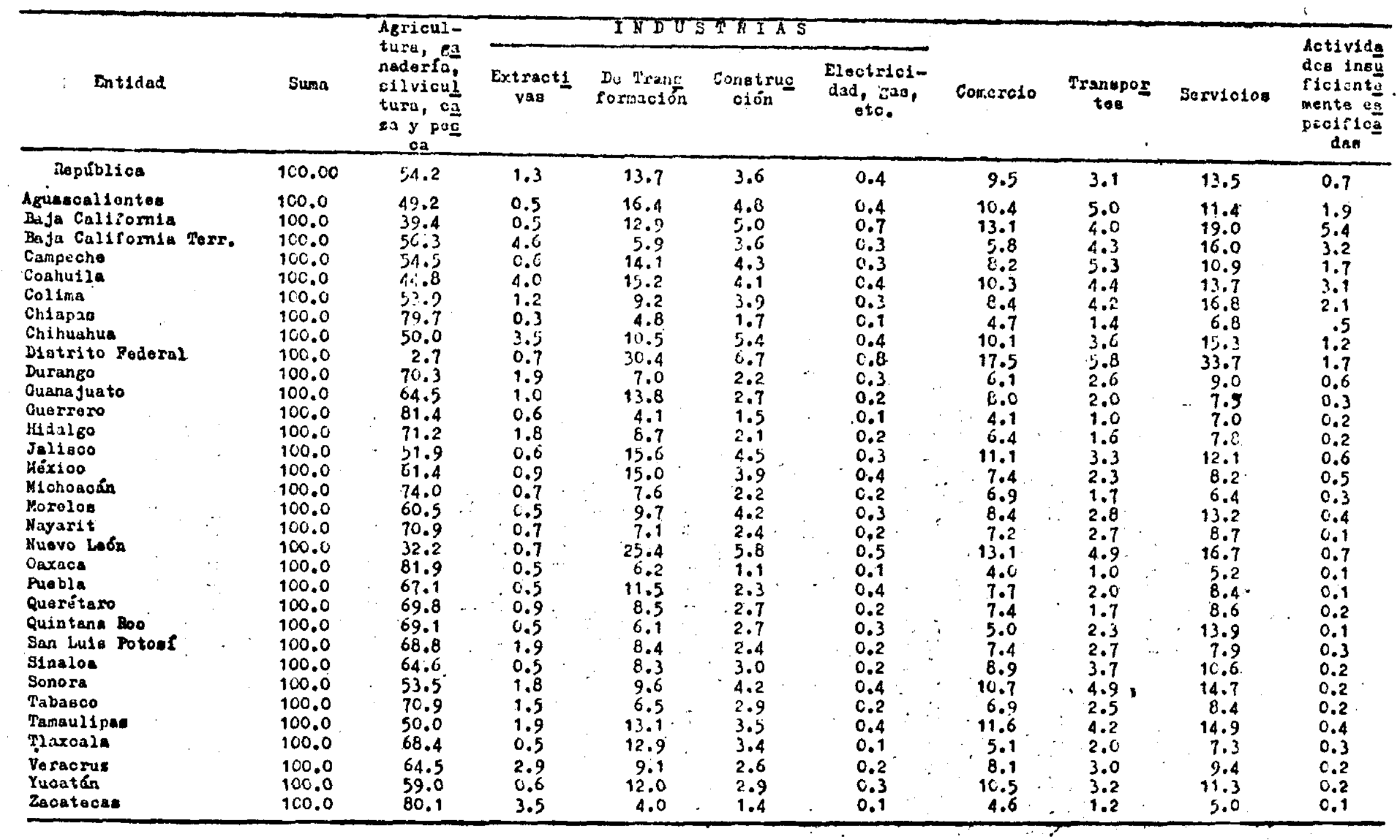

Fuente: VIII Censo General de Población, 1960. 
Cuadro 19

Méxuco: Población bconómicamente activa por entidades federativas y ramas de actividad, 1960 (Millares)

\begin{tabular}{|c|c|c|c|c|c|c|c|c|c|c|}
\hline \multirow[b]{2}{*}{ Intided } & \multirow[b]{2}{*}{ Sum } & \multirow{2}{*}{$\begin{array}{l}\text { Agrioul- } \\
\text { tura, ge } \\
\text { nadorfa, } \\
\text { allvioul } \\
\text { turs, og } \\
38 \text { g peg } \\
\text { os }\end{array}$} & \multicolumn{4}{|c|}{ IJU D STEILS } & \multirow[b]{2}{*}{ Comerolo } & \multirow[b]{2}{*}{$\begin{array}{c}\text { aranspos } \\
\text { tos }\end{array}$} & \multirow[b]{2}{*}{ Sorv10100: } & \multirow[b]{2}{*}{$\begin{array}{l}\text { dotivide } \\
\text { dos ine } \\
\text { flolonte } \\
\text { mente } \\
\text { peoifiog } \\
\text { das }\end{array}$} \\
\hline & & & $\underset{\text { ves }}{\text { Extract }}$ & $\begin{array}{l}\text { De Trans } \\
\text { Pormaofón }\end{array}$ & $\begin{array}{l}\text { Conctrug } \\
\text { olón }\end{array}$ & $\begin{array}{l}\text { Hootriol- } \\
\text { dad, gas, } \\
\text { ote. }\end{array}$ & & & & \\
\hline Dopúblion & 11331.6 & 6143.5 & $141: 5$ & 1556.1 & 408.3 & 41.3 & 1075.1 & 356.9 & 1527.2 & 81.7 \\
\hline 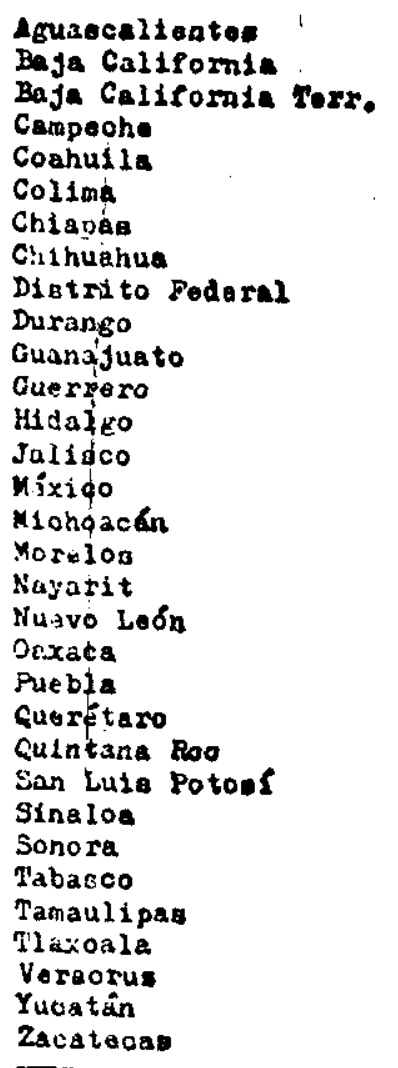 & $\begin{array}{r}77.1 \\
167.4 \\
25.9 \\
56.7 \\
288.2 \\
49.9 \\
396.8 \\
376.2 \\
1751.8 \\
235.0 \\
524.3 \\
376.3 \\
316.4 \\
757.0 \\
585.6 \\
575.0 \\
124.6 \\
120.8 \\
363.5 \\
620.9 \\
660.6 \\
112.1 \\
16.4 \\
322.0 \\
257.2 \\
250.9 \\
141.8 \\
334.5 \\
10.9 \\
84.3 \\
197.1 \\
246.9\end{array}$ & $\begin{array}{r}37.9 \\
66.0 \\
14.6 \\
30.9 \\
129.0 \\
26.9 \\
316.2 \\
187.9 \\
46.5 \\
165.2 \\
338.0 \\
306.3 \\
225.2 \\
393.1 \\
359.5 \\
425.7 \\
75.4 \\
89.8 \\
117.1 \\
507.9 \\
443.2 \\
79.2 \\
11.4 \\
281.4 \\
166.3 \\
134.4 \\
100.6 \\
167.4 \\
74.7 \\
572.7 \\
116.2 \\
197.9\end{array}$ & $\begin{array}{r}0.4 \\
0.7 \\
1.2 \\
0.3 \\
11.6 \\
0.6 \\
1.4 \\
13.2 \\
11.8 \\
4.4 \\
5.0 \\
2.3 \\
5.7 \\
4.8 \\
5.4 \\
3.8 \\
0.6 \\
6.9 \\
2.7 \\
3.2 \\
3.5 \\
1.0 \\
0.1 \\
6.1 \\
1.3 \\
4.5 \\
2.2 \\
6.2 \\
0.6 \\
26.1 \\
1.2 \\
8.7\end{array}$ & $\begin{array}{r}12.7 \\
21.6 \\
1.5 \\
8.0 \\
43.7 \\
4.6 \\
19.0 \\
.39 .4 \\
532.2 \\
16.5 \\
72.6 \\
15.5 \\
27.5 \\
118.4 \\
87.7 \\
42.5 \\
12.1 \\
9.1 \\
92.2 \\
35.4 \\
75.9 \\
9.5 \\
1.0 \\
27.1 \\
21.5 \\
24.0 \\
9.1 \\
43.7 \\
14.1 \\
90.5 \\
23.8 \\
9.7\end{array}$ & $\begin{array}{r}3.7 \\
8.4 \\
0.9 \\
2.4 \\
11.8 \\
1.9 \\
6.9 \\
20.3 \\
118.2 \\
5.1 \\
14.1 \\
5.6 \\
6.6 \\
33.7 \\
23.2 \\
12.5 \\
5.2 \\
3.1 \\
21.2 \\
6.8 \\
15.4 \\
3.1 \\
0.4 \\
7.6 \\
7.6 \\
10.6 \\
4.1 \\
11.7 \\
3.7 \\
23.2 \\
3.8 \\
3.3\end{array}$ & $\begin{array}{l}0.3 \\
1.2 \\
0.1 \\
0.2 \\
1.2 \\
0.1 \\
0.4 \\
1.5 \\
11.9 \\
0.7 \\
1.2 \\
0.4 \\
0.5 \\
2.5 \\
2.7 \\
1.4 \\
0.4 \\
0.2 \\
1.7 \\
0.6 \\
2.3 \\
0.2 \\
1.1 \\
0.6 \\
c .5 \\
0.9 \\
0.3 \\
1.2 \\
0.1 \\
2.1 \\
0.1 \\
0.3\end{array}$ & $\begin{array}{r}8.0 \\
21.9 \\
1.5 \\
4.7 \\
29.6 \\
4.2 \\
18.6 \\
38.2 \\
306.0 \\
11.3 \\
42.2 \\
15.5 \\
20.2 \\
84.0 \\
43.5 \\
39.5 \\
10.5 \\
9.2 \\
47.4 \\
21.8 \\
30.8 \\
8.3 \\
0.8 \\
24.0 \\
22.8 \\
20.9 \\
9.8 \\
38.7 \\
5.6 \\
71.7 \\
20.7 \\
11.2\end{array}$ & $\begin{array}{r}3.8 \\
6.7 \\
1.9 \\
3.0 \\
12.8 \\
2.1 \\
5.3 \\
13.5 \\
102.2 \\
6.2 \\
10.5 \\
3.7 \\
5.2 \\
24.7 \\
13.4 \\
9.9 \\
3.5 \\
3.4 \\
17.8 \\
6.5 \\
13.4 \\
2.0 \\
0.4 \\
8.8 \\
9.4 \\
12.3 \\
3.5 \\
14.2 \\
2.2 \\
20.2 \\
6.2 \\
3.0\end{array}$ & $\begin{array}{r}8.8 \\
31.9 \\
4.2 \\
6.2 \\
39.4 \\
8.4 \\
26.9 \\
57.6 \\
589.9 \\
21.2 \\
30.4 \\
26.3 \\
24.8 \\
91.7 \\
47.9 \\
37.0 \\
16.4 \\
11.0 \\
61.0 \\
32.4 \\
5 . .3 \\
9.0 \\
2.3 \\
25.4 \\
27.8 \\
36.8 \\
12.0 \\
50.0 \\
6.0 \\
83.4 \\
22.3 \\
12.5\end{array}$ & $\begin{array}{l}1.5 \\
9.0 \\
0.8 \\
1.0 \\
9.1 \\
1.1 \\
2.1 \\
4.6 \\
30.1 \\
1.4 \\
1.3 \\
0.7 \\
c .7 \\
4.1 \\
2.3 \\
1.7 \\
0.5 \\
0.1 \\
2.4 \\
0.3 \\
6.8 \\
0.2 \\
1.0 \\
0.6 \\
0.5 \\
0.2 \\
1.4 \\
0.3 \\
1.5 \\
0.3 \\
0.1\end{array}$ \\
\hline
\end{tabular}


implica serios obstáculos para llevar a cabo adecuadamente las tareas censales y estadísticas vitales. ${ }^{16}$

\section{RESUMEN}

Podríamos intentar algunas conclusiones simplemente a manera de breve recapitulación de lo que aquí se ha intentado explicar.

1) Las actividades económicas estratégicas que han determinado el desarrollo del país no han sido las mismas a lo largo de la historia de la República, ni su intensidad ha permanecido invariable. En general, puede afirmarse que el énfasis se ha trasladado de la mineria 2. la agricultura 'comercial y luego a la industria de transformación, petrolera, energía eléctrica y de construcción.

2) Hasta la segunda guerra mundial, las actividades económicas más dinámicas estuvieron ligadas casi exclusivamente a la demanda exterior.

3) A partir del segundo tercio del presente siglo, las nuevas obras de infraestructura - regadío, carreteras, abastecimiento de energía eléctrica, de petróleo y derivados, etc.- sirven de apoyo para el crecimiento económico regional pero principalmente de las áreas que gozaban ya de niveles superiores de desarrollo.

4) Indudablemente, la reforma agraria y la liberación del campesino estimularon las migraciones internas y el proceso de urbanización; además, las actividades agricolas se intensificaron en algunas regiones, aunque el período de transición del latifundio al de pequeña propiedad y al ejido haya sido pencso y a veces prolongado.

5) La colonización interna y la migración interestatal empezaron cuando el ferrocarril fue introducido en el último siglo, pero fueron acelerados a partir de la Revolución, sobre todo desde el surgimiento de ciudades de concentración industrial o de grandes áreas de agricultura comercial.

6) Se aprecia un alto grado de correlación -en el plazo largoentre el crecimiento económico, el desarrollo social y el proceso de urbanización de las entidades del país. Estos procesos se han manifestado ante_la presencia de una actividad económica dinámica, ya fuera agricultura comercial o industrialización.

7) En estas entidades, los crecimientos económico y urbano auspiciaron un rápido proceso de "terciarización" económica que continúa desarrollándose dentro de un fenómeno de causación circular de efecto-causa-efecto.

8) En las entidades que no han podido superar su estructura económica tradicional -principalmente agricultura de subsistencia- se observa un franco rezago en los indicadores económicos, sociales y de urbanización.

9) Aun más dramático es el retroceso general de entidades cuya economía se basaba casi exclusivamente en una sola actividad y que por razones ecológicas o institucionales no han podido diversificar sustancialmente su economía; así, tenemos el caso de Zacatecas, Hi-

16 En el cuadro 19, como información complementaria, se presenta la población económicamente activa por entidades federativas y ramas de actividad en 1960 . 
dalgo, Yucatán, Quintana Roo y en cierta medida San Luis Potosf, Chiapas, Guerrero y Oaxaca.

10) Aun cuando los datos estadísticos demográficos acusan cierta inconsistencia, se puede afirmar que las entidades de más alto índice de bienestar tienden a aproximarse -aunque todavía muy lejana' mente - a patrones demográficos de países más avanzados, con la natalidad tendiendo a crecer cada vez menos y habiéndose reducido notablemente la mortalidad. Investigaciones ultẹriores habrán de aclarar estos aspectos. 